ORNL/TM-12265

\title{
RECONNAISSANCE RADIOLOGICAL CHARACTERIZATION FOR THE WHITE POINT NIKE MISSILE SITE, SAN PEIIRO, CALIFORNIA
}

Date Published:

\author{
M. L. Espegren \\ M. K. Jensen \\ S. M. Smith* \\ G. A. Pierce
}

*Oak Ridge Institute of Science and Education

prepared for the

HAZWRAP SUPPORT CONTRACTOR OFFICE

Oak Ridge, Tennessee 37831 managed by

MARTIN MARIETTA ENERGY SYSTEMS, INC. for the

U.S. DEPARTMENT OF ENERGY under contract DE-ACO5-84OR21400 


\section{CONTENTS}

FIGURES $\ldots \ldots \ldots \ldots \ldots \ldots \ldots \ldots \ldots \ldots \ldots \ldots \ldots \ldots \ldots$

PLATES $\ldots \ldots \ldots \ldots \ldots \ldots \ldots \ldots \ldots \ldots \ldots \ldots \ldots \ldots \ldots \ldots$

TABLES $\ldots \ldots \ldots \ldots \ldots \ldots \ldots \ldots \ldots \ldots \ldots \ldots \ldots$ vii

EXECUTTVE SUMMARY $\ldots \ldots \ldots \ldots \ldots \ldots \ldots \ldots \ldots \ldots \ldots \ldots \ldots$

1. INTRODUCTION $\ldots \ldots \ldots \ldots \ldots \ldots \ldots \ldots \ldots \ldots \ldots \ldots \ldots$

1.1 PURPOSE $\ldots \ldots \ldots \ldots \ldots \ldots \ldots \ldots \ldots \ldots \ldots \ldots$

1.2 SITE DESCRIPTION $\ldots \ldots \ldots \ldots \ldots \ldots \ldots \ldots \ldots \ldots \ldots$

2. BACKGROUND RADIATION INVESTIGATION $\ldots \ldots \ldots \ldots \ldots \ldots$

2.1 PRESSURIZED IONIZATION CHAMBER (PIC)

AND BACKGROUND MEASUREMENTS $\ldots \ldots \ldots \ldots \ldots 3$

2.2 CORRELATION OF PIC MEASUREMENTS TO LOCAL GEOLOGY ..................... 4

3. ALPHA AND BETA-GAMMA RADIATION INVESTIGATIONS

AND SOIL SAMPLING $\ldots \ldots \ldots \ldots \ldots \ldots \ldots \ldots \ldots \ldots$

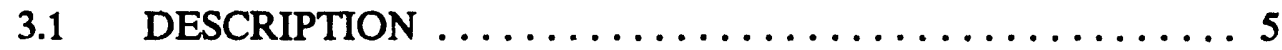

3.2 FIELD ALPHA AND BETA-GAMMA RADIATION SURVEY METHODS AND PROCEDURES $\ldots \ldots \ldots \ldots \ldots \ldots$

3.3 ALPHA AND BETA-GAMMA RADIATION SURVEY RESULTS .......................6

3.4 SOIL ALPHA, BETA, AND GAMMA RADIATION SAMPLING METHODS AND PROCEDURES . . . . . . 6

3.5 SOIL SAMPLE RESULTS $\ldots \ldots \ldots \ldots \ldots \ldots \ldots \ldots$

3.6 DISCUSSION $\ldots \ldots \ldots \ldots \ldots \ldots \ldots \ldots \ldots \ldots \ldots$

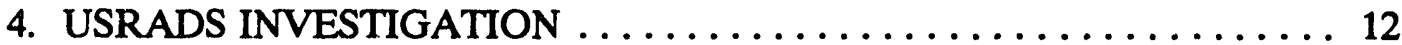

$4.1 \quad$ DESCRIPTION $\ldots \ldots \ldots \ldots \ldots \ldots \ldots \ldots \ldots \ldots \ldots \ldots \ldots$

4.2 USRADS METHODS AND PROCEDURES $\ldots \ldots \ldots \ldots \ldots 13$

$4.3 \quad$ USRADS SURVEY RESULTS $\ldots \ldots \ldots \ldots \ldots \ldots \ldots \ldots \ldots$

$4.4 \quad$ DISCUSSION $\ldots \ldots \ldots \ldots \ldots \ldots \ldots \ldots \ldots \ldots \ldots$ 
5. INDOOR RADIATION INVESTIGATION $\ldots \ldots \ldots \ldots \ldots \ldots \ldots \ldots$

5.1 DESCRIPTION ..................... 21

5.2 INDOOR SURVEY METHODS AND PROCEDURES . . . 27

5.3 INDOOR SURVEY RESULTS . . . . . . . . . . 29

5.4 DISCUSSION $\ldots \ldots \ldots \ldots \ldots \ldots \ldots \ldots \ldots \ldots \ldots \ldots \ldots \ldots$

6. SUMMARY AND CONCLUSIONS $\ldots \ldots \ldots \ldots \ldots \ldots \ldots \ldots \ldots$

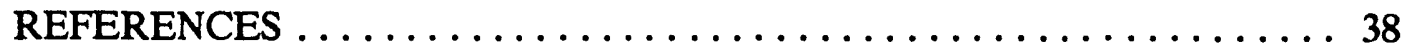

ACRONYMS AND INITIALISMS $\ldots \ldots \ldots \ldots \ldots \ldots \ldots \ldots \ldots \ldots$ 


\section{FIGURES}

5.1 White Point Nike Missile Site, Bldg. $1026 \ldots \ldots \ldots \ldots \ldots 22$

5.2 White Point Nike Missile Site, Bldg. $1027 \ldots \ldots \ldots \ldots \ldots \ldots$

5.3 White Point Nike Missile Site, Bldg. 1019, east silo . . . . . . . . 25

5.4 White Point Nike Missile Site, Bldg. 1020, west silo . . . . . . . . 26

\section{PLATES}

1. ORNL/PAG regional geologic map with PIC locations - White Point Nike Missile Site

2. Alpha, beta-gamma radiation survey and soil sample locations - White Point Nike Missile Site, San Pedro, California

3. USRADS survey - White Point Nike Missile Site, San Pedro, California 


\section{TABLES}

3.1 Alpha, beta-gamma, and gamma radiation field measurements . . . . 7

3.2 Soil sample results $\ldots \ldots \ldots \ldots \ldots \ldots \ldots \ldots \ldots \ldots \ldots \ldots \ldots$

4.1 USRADS data for White Point Nike Missile Site ........... 15

5.1 Surface radioactivity guides $\ldots \ldots \ldots \ldots \ldots \ldots \ldots \ldots \ldots \ldots \ldots \ldots$

$5.2 \quad$ Results of interior survey direct readings $\ldots \ldots \ldots \ldots \ldots \ldots \ldots$

$5.3 \quad$ Interior survey smear results $\ldots \ldots \ldots \ldots \ldots \ldots \ldots \ldots \ldots \ldots$ 


\section{EXECUTTVE SUMMARY}

This report is the result of field work performed at the former White Point Nike Missile Site, San Pedro, Calif. The Hazardous Waste Remedial Actions Program tasked the Oak Ridge National Laboratory Pollutant Assessments Group in Grand Junction, Colo., with this project. The objective was to determine whether or not radioisotopes possibly associated with past Department of Defense (DOD) operations were present and within accepted background levels.

The radiation survey was accomplished by performing three independent radiation surveys, both outdoors and indoors, and random soil sampling. Initially, the site was land surveyed to develop a grid block system. A background radiation investigation was performed out in the San Pedro area.

The gamma radiation survey was performed using the automated Ultrasonic Ranging and Data System (USRADS). The blocks investigated included roadways and building access areas, assuming that any man-made contamination would be associated with transport and assembly equipment. Portions of some blocks could not be surveyed using USRADS because of terrain constraints; a walk-on gamma radiation scan was performed instead with a hand-held scintillometer.

Alpha and beta-gamma radiation measurements were taken at predetermined coordinates using hand-held instruments. The soil sample investigation was performed by taking random samples at the same coordinates as the alpha and beta-gamma radiation measurements.

An indoor radiation survey was conducted in Buildings 1026 and 1027 and in the missile silos. Four readings above guidelines were located in the west silo. Smears were taken at these locations; readings were near background levels. Elevated readings are believed to be due to radon.

The majority of the outdoor and indoor measurements were within acceptable limits. All anomalous measurements were explained. The conclusion was that no man-made contamination associated with past DOD operation existed on the White Point site. 


\section{INTRODUCTION}

\subsection{PURPOSE}

The Hazardous Waste Remedial Actions Program (HAZWRAP) of Martin Marietta Energy Systems, Inc., provides technical and administrative support for the U. S. Department of Defense (DOD) Installation Restoration Program (IRP). Designed to investigate and remediate hazardous contaminants on abandoned properties resulting from past operations, the IRP is conducted according to guidelines established for the Comprehensive Environmental Response, Compensation, and Liability Act (CERCLA). U. S. Environmental Protection Agency (EPA) standards are used for radioactivity guidelines. Oak Ridge National Laboratory (ORNL), managed by Martin Marietta Energy Systems, Inc., provides technical assistance to HAZWRAP in the support of the IRP.

The ORNL/Pollutant Assessments Group (PAG), Grand Junction, Colo., was tasked with the radiological characterization of the White Point Nike Missile Site (White Point) by HAZWRAP. Some Nike missile warheads were known to contain depleted uranium. However, it is not known if these types of missiles were present at the site. Therefore, the purpose of the characterization was to determine if radiological contamination existed from Nike missile storage and dismantling at the site. This report is a result of that radiological characterization. Each section of the report describes specific aspects and results of the field work.

The characterization was performed according to the following documents: the site work plan (ORNL 1991a), Quality Control Requirements for Field Methods (HAZWRAP 1990b), Requirements for Quality Control of Analytical Data (HAZWRAP 1990c), and the Pollutant Assessments Group Procedures Manual (ORNL 1991b). Because there is no evidence indicating the presence of other than naturally occurring radionuclides at the White Point site, the work plan was written to use survey methods and soil sampling techniques that would confirm the absence of exposure levels above background. 
Field work consisted of several tasks: establishment of a surveyed grid block system, a gamma radiation survey by the Ultrasonic Ranging and Data System (USRADS), an outdoor alpha and beta-gamma radiation survey on a grid system, an unbiased soil sample investigation, and an indoor alpha and beta/gamma radiation survey. Before radiation surveying could begin, a grid system was established by land survey on the site. Each grid block was $61 \times 61 \mathrm{~m}(200 \times 200 \mathrm{ft})$, giving a total of 175 grid blocks. The alpha, beta, and gamma radiological surveys were performed simultaneously after the grid system was surveyed.

\subsection{SITE DESCRIPTION}

White Point is located at San Pedro, Calif., in the city of Los Angeles. Plate 1 shows the site and the surrounding area. In the early 1940s, approximately 175 acres were acquired by the federal government for seacoast battery harbor defenses and were made part of Fort MacArthur. Two 16-in. gun emplacements were constructed on the site. After World War II, the guns were dismantled; however, the concrete housing structures remain on the site (HAZWRAP 1990a).

In the mid-1950s, White Point became a Nike missile battery. The Nike Air Defense Program was discontinued in the early 1970s, and the site was declared excess. Several buildings, the concrete pad surrounding the missile silos, and evidence of an abandoned landfill slightly west of center of the site remain on the site. The Los Angeles Park Service was in the process of renovating Building 1027 while the ORNL/PAG personnel were on site. Park personnel who visited the site during field work indicated that the building will be used for living quarters for a park ranger when a portion of the site is made into a city park. Part of the site is currently deeded to the city of Los Angeles, and the rest is overseen by the U. S. Air Force (HAZWRAP 1990a). Because of the isolated nature of the site, Military Police (MPs) from Fort MacArthur visited the ORNL/PAG field crew on several occasions and were present during the initial descent into the silos. 
White Point is situated in the coastal zone. The ocean lies to the south beyond the cliffs, and the remainder of the site is surrounded by residential houses. The coastline in this area is comprised of headlands and coves with White Point as one of the headlands. Physical characteristics of the site include marine terraces and steep slopes. The elevation ranges from 100 to $400 \mathrm{ft}$ above mean sea level (MSL). The climate is mild and westerly winds prevail (HAZWRAP 1990a).

\section{BACKGROUND RADIATION INVESTIGATION}

\section{PRESSURIZED IONIZATION CHAMBER (PIC) AND BACKGROUND MEASUREMENTS}

Gamma radiation at White Point was measured using gamma radiation scintillometers that read in thousands of counts per minute (kcpm). In order to convert scintillometer counts to exposure rates in microroentgens per hour $(\mu R / \mathrm{h})$, a conversion curve was formulated by taking corresponding gamma scintillometer measurements and PIC measurements in identical locations and performing a linear regression.

Twenty-six correlative measurements were taken for the White Point curve. The measurements were taken at the site and the surrounding area at public locations in the San Pedro region. The locations are indicated on Plate 1. A linear regression was performed on the numbers with the PIC measurements along the $y$ axis and the scintillometer measurements along the $x$ axis. The resulting correlation formula, $\mu \mathrm{R} / \mathrm{h}=2.05 \mathrm{kcpm}+2.79$, was used to convert all gamma radiation measurements taken at the site.

Background gamma radiation exposure rates and $\mathrm{pCi} / \mathrm{g}$ limits for soils for the White Point site were established by taking measurements both on and off site. The average background gross gamma radiation rate calculated from these measurements was 4500 counts per minute (cpm), which converts to an average 
gamma radiation of $12 \mu \mathrm{R} / \mathrm{h}$ using the above formula. Background alpha radiation, beta-gamma radiation, and soil sample measurements were taken at South Shores School (Plate 1). The school ground was scanned for gamma radiation prior to taking measurements to ensure that no contamination existed. The alpha radiation background was determined to be 0 to $2 \mathrm{dpm} / \mathrm{cm}^{2}$ (disintegrations per minute per square centimeter). The beta-gamma radiation background was determined to be $50 \mathrm{dpm} / \mathrm{cm}^{2}$. Locations of the measurements are shown on Plate 1.

\subsection{CORRELATION OF PIC MEASUREMENTS TO LOCAL GEOLOGY}

White Point is part of the Palos Verdes Hills geological region. The geological structure of the hills is anticlinal with a major fault to the north and a minor fault off shore to the south. The uplifted fault block is along the south-western edge of the Los Angeles Basin. The structure is relatively simple with the majority of deformation (i.e., faulting and folding) existing in the White Point area. A fold can be seen along the shoreline near the lifeguard station at Royal Palms Beach (U.S.DOI 1946).

The stratigraphy of the region consists of a metamorphic basement overlain by marine deposits of Miocene, Pliocene, and Pleistocene age. The bedrock on the site is the Miocene Altamira Shale Member of the Monterey Formation. The Altamira Shale consists of interbedded siltstones, shales, and sandstones with localized silicification resulting in cherty deposits. Other rock units evident at the site include nonmarine terrace cover, marine terrace deposits, and the Palos Verdes sands (Plate 1). A tuff is reported to exist in the Palos Verdes Hills region but was not observed during this reconnaissance field work at White Point (U.S.DOI 1946; HAZWRAP 1990a). A fossil was found by a ORNL/PAG field crew member during the USRADS survey. Consisting of large rib-like and vertebrae bones in a shale matrix, the fossil was left intact, and Fort MacArthur was alerted to its presence. Fort MacArthur personnel were to investigate the fossil after field work was finished. 
In general, radioactive elements do not occur in abundance in the deposits of the Palos Verdes Hills region, and the background gamma radiation exposure rates found during field work in this area are consistent with that lithology. However, the anoxic conditions under which diatomaceous sediments are deposited, like the marine shales of the area, are conducive to the geochemistry of uranium. The Monterey Formation appears to have a higher uranium content than do most other shales of its type (USGS 1987). Localized pockets of uranium deposition most likely account for the anomalous gamma radiation exposure rates found on the site as described in Sect. 3.5.

\section{ALPHA AND BETA-GAMMA RADIATION INVESTIGATIONS AND SOIL SAMPLING}

\subsection{DESCRIPTION}

Field surveys for alpha and beta-gamma radiation were performed at White Point at 83 of the 85 predetermined locations. Two grid blocks were located in an area that had been eroded by the shoreline and no longer existed. The surveys were performed using a Bicron ${ }^{m}$ Analyst meter and probe for detecting alpha radiation and a Ludlum ratemeter and Geiger-Muller pancake probe for detecting beta-gamma radiation. Gamma radiation exposure rate readings were also taken at these locations using a Victoreen portable gamma radiation scintillometer. In addition, soil samples were taken at $10 \%$ of the survey locations at predetermined, random locations. Soil samples were also taken at three locations identified by the USRADS survey. Spectral analyses of all samples were performed by Controls for Environmental Pollution (CEP), a HAZWRAP-reviewed laboratory located in Santa Fe, N.M. 


\subsection{FIELD ALPHA AND BETA-GAMMA RADIATION SURVEY METHODS AND PROCEDURES}

The statistical method used for selecting specific survey locations is outlined in the work plan (ORNL 1991a). This method was selected to eliminate bias in the estimated mean of alpha- and beta-emitting radionuclide concentrations. Some of the coordinates had to be adjusted due to the presence of concrete slabs, inaccessible terrain, or shoreline position. These coordinates were moved in $1-\mathrm{m}$ increments to the nearest surface-soil location, and the new coordinates were noted in the field logbook. These are presented on Plate 2.

\subsection{ALPHA AND BETA-GAMMA RADIATION SURVEY RESULTS}

The results for the alpha, beta-gamma, and gamma radiation survey measurements are presented in Table 3.1. All readings were below the guidelines specified in DOE Order 5480.11 (U.S.DOE 1990a).

\subsection{SOIL ALPHA, BETA, AND GAMMA RADIATION SAMPLING METHODS AND PROCEDURES}

Samples were taken within $1 \mathrm{~m}$ of alpha and beta-gamma radiation measurements. Samples were taken with post-hole diggers and placed on plastic sheets. Gamma radiation scintillometer measurements were taken on the surface (depth of 0-15 cm) and at each subsequent sampling depth $(15-30 \mathrm{~cm})$ to check for an increase in gamma radiation rates greater than 20\% (ORNL 1991b, Procedure TE-020). Each sample was blended and approximately $500 \mathrm{~g}$ placed in an aluminum can. Cans were labeled with four-digit field numbers and placed in a plastic bags. All samples were placed in a cooler and shipped to CEP for analysis of gross alpha, gross beta, and gross gamma radiation. Chain-of-custody forms and custody seals accompanied all samples. Two duplicate samples and two matrix spike 
Table 3.1. Apba, beta-gamma, and gamma radiation field measurements

\begin{tabular}{|c|c|c|c|c|}
\hline Grid Block & Coordinates & $\begin{array}{c}\text { Alphs, } \\
\text { dpm/100 } \mathrm{cm}^{2}\end{array}$ & $\begin{array}{l}\text { Beta-Gamma, } \\
\text { dpm/100 } \mathrm{cm}^{2}\end{array}$ & $\begin{array}{l}\text { Gamma, } \\
\mu \mathrm{R} / \mathbf{h}\end{array}$ \\
\hline $\mathrm{I}-15$ & $45,13^{*}$ & bkgd & 1344 & 12 \\
\hline $\mathrm{J}-15$ & 45,04 & 22 & 1613 & 10 \\
\hline $\mathrm{K}-15$ & $45,09^{*}$ & 44 & 484 & 10 \\
\hline $\mathrm{H}-14$ & 45,16 & bkgd & $1 \mathrm{~L} / 5$ & 9 \\
\hline I-14 & 45,03 & bkgd & 1075 & 9 \\
\hline $\mathrm{J}-14$ & 45,39 & bkgd & 860 & 10 \\
\hline K-14 & 45,07 & 44 & 591 & 9 \\
\hline L-14 & $61,18^{*}$ & 22 & 860 & 10 \\
\hline $\mathrm{H}-13$ & 61,04 & bkgd & 1344 & 9 \\
\hline I-13 & 51,11 & bkgd & 376 & 9 \\
\hline$J-13$ & 61,44 & bkgd & 1237 & 9 \\
\hline $\mathrm{K}-13$ & 61,33 & bkgd & 1075 & 10 \\
\hline L-13 & 61,21 & bkgd & 968 & 10 \\
\hline M-13 & 61,16 & bkgd & 1022 & 8 \\
\hline $\mathrm{N}-13$ & 61,03 & bkgd & 484 & 9 \\
\hline F-12 & 09,26 & 30 & 1398 & 11 \\
\hline G-12 & 09,04 & 68 & 1613 & 10 \\
\hline $\mathrm{H}-12$ & 09,11 & bkgd & 645 & 10 \\
\hline $\mathrm{N}-12$ & 09,39 & bkgd & 323 & 10 \\
\hline P-12 & 09,07 & 22 & 1022 & 9 \\
\hline E-11 & 17,26 & bkgd & 914 & 10 \\
\hline F-11 & 17,04 & 15 & 699 & 10 \\
\hline G-11 & 17,11 & 15 & 699 & 10 \\
\hline $\mathrm{H}-11$ & 17,44 & 8 & 860 & 10 \\
\hline P-11 & 50,36 & bkgd & 538 & 10 \\
\hline Q-11 & 50,09 & 29 & 215 & 9 \\
\hline R-11 & 50,10 & bkgd & 806 & 9 \\
\hline E-10 & 50,11 & 8 & 914 & 9 \\
\hline$F-10$ & 50,44 & 30 & 1183 & 10 \\
\hline R-10 & 57,04 & bkgd & 108 & 10 \\
\hline F-9 & 57,21 & 15 & 753 & 10 \\
\hline H-9 & 57,03 & bkgd & 1559 & 9 \\
\hline I-9 & 57,39 & 23 & 838 & 9 \\
\hline J-9 & $57,04^{*}$ & 14 & 1099 & 10 \\
\hline K-9 & 10,36 & 18 & 157 & 9 \\
\hline F-8 & 10,39 & bkgd & 860 & 10 \\
\hline H-8 & 30,36 & 15 & 1290 & 10 \\
\hline I-8 & 30,09 & bkgd & 628 & 10 \\
\hline J-8 & 30,10 & 4 & 419 & 9 \\
\hline K-8 & 30,26 & 30 & bkgd & 11 \\
\hline L-8 & 30,04 & 45 & 1129 & 8 \\
\hline M-8 & 30,11 & 30 & 1344 & 9 \\
\hline N-8 & 30,44 & bkgd & bkgd & 10 \\
\hline F-7 & 54,09 & bkgd & 968 & 9 \\
\hline
\end{tabular}




\section{8}

Table 3.1. (continued)

\begin{tabular}{|c|c|c|c|c|}
\hline Grid Block & Coordinates & $\begin{array}{l}\text { Alpha, } \\
\text { dpm/100 } \mathrm{cm}^{2}\end{array}$ & $\begin{array}{l}\text { Beta-Gamma, } \\
\text { dpm/100 cm }\end{array}$ & $\begin{array}{c}\text { Gamma, } \\
\mu R / h\end{array}$ \\
\hline G-7 & 54,10 & 30 & 699 & 10 \\
\hline $\mathrm{H}-7$ & 54,26 & 23 & 269 & 10 \\
\hline I-7 & 54,04 & bkgd & 524 & 10 \\
\hline J-7 & 54,11 & 23 & bkgd & 10 \\
\hline K-7 & 54,44 & 15 & bkgd & 9 \\
\hline L-7 & 54,33 & bkgd & 430 & 9 \\
\hline M-7 & 54,21 & bkgd & 1075 & 9 \\
\hline N-7 & 54,16 & bkgd & 1505 & 10 \\
\hline P-7 & 54,03 & bkgd & bkgd & 10 \\
\hline Q-7 & 54,39 & 8 & bkgd & 9 \\
\hline R-7 & 54,07 & 38 & bkgd & 10 \\
\hline G-6 & 23,44 & bkgd & 591 & 9 \\
\hline $\mathrm{H}-6$ & 23,33 & bkgd & 914 & 10 \\
\hline $\mathrm{I}-6$ & 23,21 & 38 & 914 & 9 \\
\hline$J-6$ & 23,16 & 15 & 215 & 10 \\
\hline $\mathrm{K}-6$ & 23,03 & 30 & bkgd & 9 \\
\hline L-6 & 23,39 & 30 & bkgd & 10 \\
\hline M-6 & $23,13^{*}$ & 8 & bkgd & 10 \\
\hline N-6 & 29,36 & 15 & bkgd & 10 \\
\hline A-5 & 29,04 & 15 & 645 & 10 \\
\hline B-5 & 29,11 & 38 & 419 & 9 \\
\hline C-5 & 29,44 & 45 & 995 & 10 \\
\hline D-5 & $29,31^{*}$ & 8 & 105 & 9 \\
\hline E-5 & 29,21 & 45 & 576 & 9 \\
\hline F-5 & 29,16 & 38 & 628 & 9 \\
\hline L-5 & $30,00^{*}$ & 23 & 628 & 9 \\
\hline M-5 & 30,26 & 45 & 1047 & 9 \\
\hline N-5 & $30,37^{*}$ & 53 & 838 & 9 \\
\hline A-4 & $30,30^{*}$ & bkgd & 323 & 8 \\
\hline D-4 & $30,61^{*}$ & 68 & 524 & 9 \\
\hline E-4 & $30,30^{*}$ & 53 & 628 & 9 \\
\hline L-4 & $53,21^{*}$ & 30 & 1571 & 9 \\
\hline E-3 & $53,30^{*}$ & bkgd & 52 & 10 \\
\hline F-3 & 53,21 & 7 & bkgd & 9 \\
\hline G-3 & 53,16 & bkgd & bkgd & 7 \\
\hline $\mathrm{H}-3$ & $30,00^{*}$ & bkgd & bkgd & 9 \\
\hline $\mathrm{K}-3$ & $33,52 *$ & 45 & 628 & 9 \\
\hline $\mathrm{I}-2$ & Inaccessible & & & \\
\hline $\mathrm{J}-2$ & 33,26 & 30 & bkgd & 9 \\
\hline $\mathrm{K}-2$ & $30,61 *$ & 45 & 419 & 9 \\
\hline $\mathrm{J}-1$ & Inaccessible & & & \\
\hline
\end{tabular}

Coordinates were adjusted due to presence of concrete or other barriers. bkgd = readings at or below the background reading. 
9

samples were taken for laboratory quality control (HAZWRAP 1990c). After sampling, all visible residue was removed from sampling equipment at the sample location using brushes, paper towels, and water.

\subsection{SOIL SAMPLE RESULTS}

Five surface and five subsurface soil samples were taken at the South Shores School to determine off-site background levels. Ten each surface and subsurface samples were taken at predetermined coordinates. The USRADS survey identified three locations with gamma radiation exposure rate anomalies, that is, areas with readings greater than background levels. Four surface and four subsurface soil samples were taken at these locations. The samples were taken at the two points with the highest gamma radiation exposure rates. All sample results are presented in Table 3.2 .

\subsection{DISCUSSION}

Alpha and beta-gamma radiation readings at White Point were within the ranges detected at South Shores School. Background soil samples taken at the South Shores School ranged from $0.4 \mathrm{pCi} / \mathrm{g}$ to $8.5 \mathrm{pCi} / \mathrm{g}$. Samples from the predetermined locations ranged from $1.0 \mathrm{pCi} / \mathrm{g}$ to $8.6 \mathrm{pCi} / \mathrm{g}$. Eleven of the twelve samples taken at the locations determined by the USRADS survey yielded results exceeding background readings and also guidelines of $5 \mathrm{pCi} / \mathrm{g}$ and $15 \mathrm{pCi} / \mathrm{g}$ above background averaged over $100 \mathrm{~m}^{2}$ (40 CFR 192). These samples ranged from $8.8 \mathrm{pCi} / \mathrm{g}$ to $53.9 \mathrm{pCi} / \mathrm{g}$. The shale outcrop observed toward the upper center of the site most likely contains elevated uranium, thus causing the anomalous gamma radiation exposure rates found by the USRADS. The Monterey Formation located on the site contains above normal concentrations of naturally occurring uranium (USGS 1987). This shale was observed to outcrop only in the center of the site, explaining the anomalous readings found only at this location. 
Table 3.2 Soil sample results

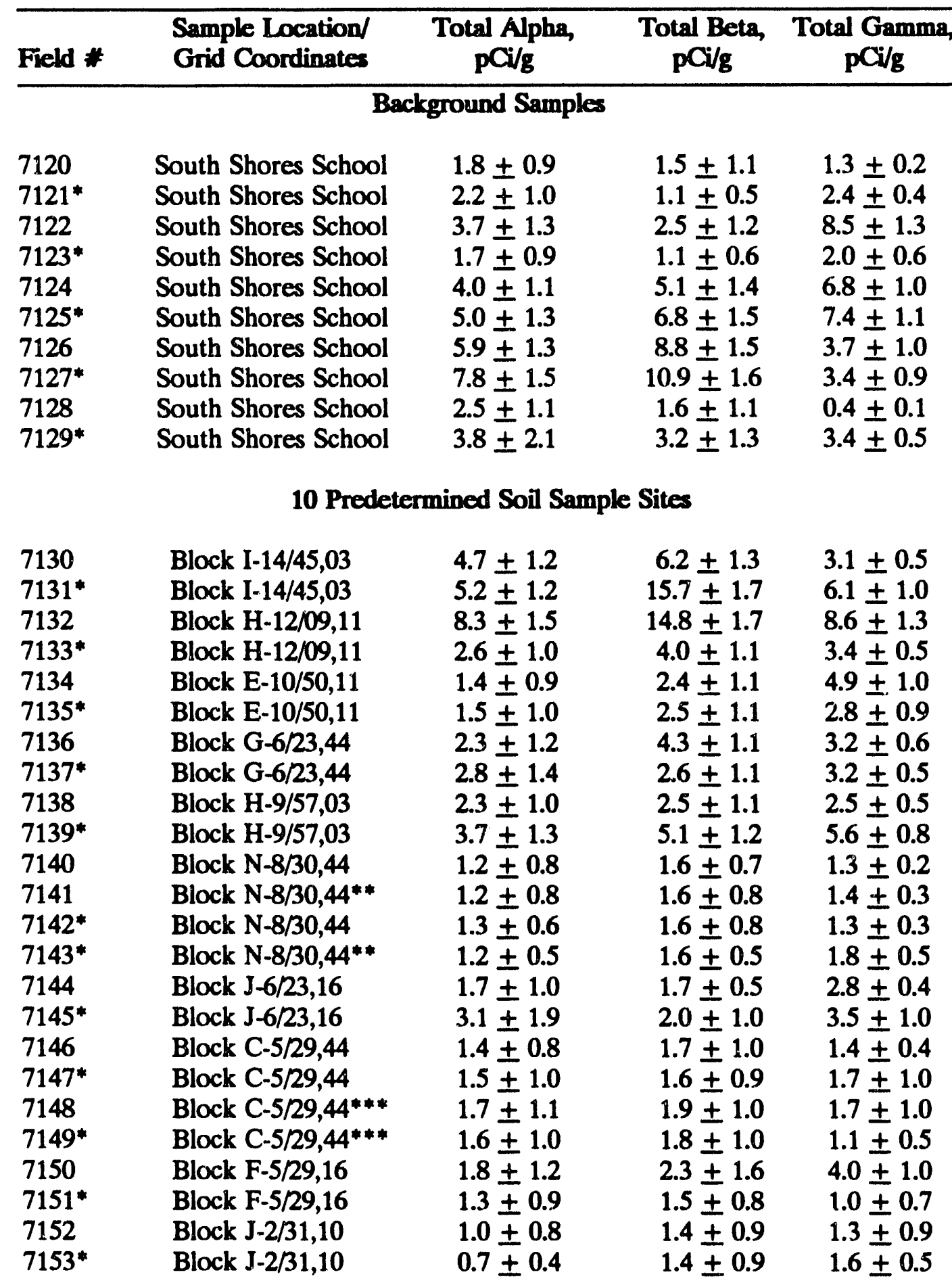


Table 3.2 (continued)

\begin{tabular}{llrrr}
\hline Field \# & $\begin{array}{c}\text { Sample Location/ } \\
\text { Grid Coordinates }\end{array}$ & $\begin{array}{c}\text { Total Alpha, } \\
\text { pCi/g }\end{array}$ & $\begin{array}{c}\text { Total Beta, } \\
\text { pCi/g }\end{array}$ & $\begin{array}{c}\text { Total Gamma, } \\
\text { pCi/g }\end{array}$ \\
\hline \multicolumn{7}{c}{ Additional Soil Sample Locations Identified by USRADS Survey } \\
7154 & Block L-13/51,49 & $1.6 \pm 1.1$ & $1.4 \pm 0.7$ & $8.8 \pm 4.8 \#$ \\
$7155^{*}$ & Block L-13/51,49 & $2.7 \pm 1.3$ & $6.6 \pm 1.7$ & $9.3 \pm 3.7 \#$ \\
7156 & Block L-13/50,49 & $1.8 \pm 1.0$ & $3.4 \pm 1.5$ & $9.9 \pm 1.5 \#$ \\
$7157^{*}$ & Block L-13/50,49 & $2.2 \pm 1.2$ & $3.3 \pm 1.5$ & $10.8 \pm 2.9 \#$ \\
7158 & Block H-13/24,37 & $19.0 \pm 2.2$ & $22.2 \pm 2.3$ & $22.8 \pm 3.9 \#$ \\
$7159^{*}$ & Block H-13/24,37 & $15.9 \pm 2.1$ & $23.0 \pm 2.3$ & $13.7 \pm 6.5 \#$ \\
7160 & Block H-13/25,35 & $6.1 \pm 1.5$ & $8.1 \pm 1.7$ & $8.1 \pm 2.5$ \\
$7161^{*}$ & Block H-13/25,35 & $21.8 \pm 2.4$ & $30.9 \pm 2.6$ & $53.9 \pm 3.1 \#$ \\
7162 & Block H-9/23,26 & $9.2 \pm 1.8$ & $10.1 \pm 1.8$ & $18.1 \pm 2.4 \#$ \\
$7163^{*}$ & Block H-9/23,26 & $5.6 \pm 1.6$ & $6.6 \pm 1.7$ & $9.0 \pm 1.4 \#$ \\
7164 & Block H-9/22,26 & $7.9 \pm 1.6$ & $11.7 \pm 2.0$ & $12.0 \pm 3.2 \#$ \\
$7165^{*}$ & Block H-9/22,26 & $4.9 \pm 1.7$ & $3.2 \pm 1.6$ & $12.8 \pm 2.8 \#$ \\
& & & & \\
\hline
\end{tabular}

* Subsurface 15 to 30 -cm soil samples

** Duplicate samples

*** Matrix spike samples

\# Anomalous gamma readings 
Further analysis of samples for specific elements such as uranium confirmed these findings. The samples were sent to the ORNL Health and Safety Research Division (HASRD) and analyzed by the $\mathrm{Ge}(\mathrm{Li})$ detector system. The elements were found to be in equilibrium, indicating naturally occurring uranium in the soils.

\section{USRADS INVESTIGATION}

\subsection{DESCRIPTION}

A gamma radiation survey of White Point was conducted using USRADS. The blocks chosen to be surveyed consisted of those on roadways, areas surrounding buildings, and related access areas because disturbed areas are more likely to exhibit contamination than undisturbed areas. Portions of the chosen blocks could not be surveyed with USRADS due to the steep terrain and thick underbrush that precluded proper van location for optimum transmission or valid positioning of the stationary receivers. The parts of the blocks that could not be covered with USRADS were surveyed by walk-on methods using hand-held gamma radiation scintillometers.

Some blocks in the southern portion of the study site could not be surveyed by USRADS or walk-on survey because of vertical cliffs or shoreline erosion. Steep hillsides were surveyed, when accessible, using walk-on methods along the shoreline. The existing shoreline was adjusted on all maps when field observations showed discrepancies.

Thick brush present on the site during field work interfered with accessibility of certain areas. Much of the ground in the study blocks was professionally mowed by a subcontractor to improve accessibility. 


\subsection{USRADS METHODS AND PROCEDURES}

USRADS is a patented, computerized data acquisition system developed by ORNL to collect and relate data from field-portable instruments to the precise physical location of the data points. Chemrad Tennessee Corporation (Chemrad) currently holds the license to manufacture or lease commercial versions of USRADS. USRADS incorporates three technologies: 1) radio frequency (RF) communications, 2) ultrasonics, and 3) a personal computer (PC) (Berven 1991). The hardware consists of a surveyor's backpack, fifteen stationary receivers, a master receiver, a custom computer interface, and a PC. The system is adaptable to many field-portable instruments such as gamma-ray detectors or electromagnetic geophysical instruments. A portable gamma-ray detector was connected to the system used at White Point.

RF is used for system timing, communications, and data transfer. The propagation time of an ultrasonic signal serves as a device to measure the distance travelled while scanning. The PC is used to: 1) calculate the surveyor position; 2) reduce, store, and display data; 3) prepare reports; and 4) transfer data into electronic data bases.

USRADS is able to obtain a maximum of 3600 readings per hour of survey time, allowing thorough, documented site coverage and accurate data gathering. The surveyor's position is plotted on the PC screen, creating a track map (Plate 3). Areas not covered are easy to discern with the track map. The missed areas can be surveyed while the crew is mobilized at a particular site.

The maximum effective distance between the surveyor and the stationary receiver is $80 \mathrm{~m}$ ( $260 \mathrm{ft})$. This distance dictated the grid block size of $61 \times 61 \mathrm{~m}$ $(200 \times 200 \mathrm{ft})$ at White Point. The survey was conducted with the surveyor walking within each grid block on 3-m (10-ft) centers, thus providing adequate coverage by the instruments for detecting any possible gamma-radiation anomalies existing on the site. The surveyor moves the portable gamma radiation scintillometer probe from side to side while walking forward, holding the probe as close to the ground as possible. 


\subsection{USRADS SURVEY RESULTS}

A consolidated track map of the USRADS survey is provided on Plate 3, showing actual site coverage during the survey. Gamma radiation exposure rate ranges obtained during walk-on surveys are also shown on Plate 3.

A threshold of $5500 \mathrm{cpm}(14 \mu \mathrm{R} / \mathrm{h})$ was established as 2 sigma above average background levels and entered into the USRADS personal computer to determine elevated readings (ORNL, 1991b).

USRADS calculated minimum, maximum, mean, and standard deviation values in counts per minute (cpm) for each block. These data were converted to exposure rates in $\mu \mathrm{R} / \mathrm{h}$ and are shown in Table 4.1 .

\subsection{DISCUSSION}

The USRADS and walk-on surveys determined that seventy blocks were at or below 2 sigma above average background. Following identification of anomalous readings, a hand-held gamma radiation scintillometer was used to verify these regions, and the highest gamma radiation exposure rate was located. The elevated region in block $\mathrm{R} 7$ was determined to be from naturally occurring radiation inherent in the cinder blocks of Building 1030. Blocks H9, H13, and L13 exhibited gamma radiation exposure rate anomalies that exceeded 2 sigma above average background when investigated by a scintillometer during a walk-on survey. Soil samples were collected in blocks $\mathrm{H} 9, \mathrm{H} 13$, and L13 and sent to the laboratory for analysis. Soil results are presented in Table 3.2.

Blocks E10, J7, K7, M13 and N13 exhibited anomalous readings using USRADS. However, a detailed investigation of these blocks during a walk-on survey showed no elevated measurements. Because system error was suspected, the data were sent to a Chernrad consultant with USRADS expertise. 
Table 4.1. USRADS data for White Point Nike Missile Site

\begin{tabular}{|c|c|c|c|c|}
\hline $\begin{array}{l}\text { Block } \\
\text { Number }\end{array}$ & $\underset{\mu R / h}{\text { Minimum }}$ & $\begin{array}{l}\text { Mean } \\
\mu \mathbf{R} / \mathbf{h}\end{array}$ & $\begin{array}{l}\text { Maximum } \\
\mu R / h\end{array}$ & Comments \\
\hline A4 & $N U^{*}$ & $\mathrm{NU}^{\mathbf{2}}$ & $N^{2}$ & $\begin{array}{l}\text { Block A4 consisted of shore- } \\
\text { line boulders and ocean front } \\
\text { and was not surveyed. }\end{array}$ \\
\hline $\begin{array}{l}\text { A5 \& } \\
\text { B5 }\end{array}$ & 8 & 10 & 12 & $\begin{array}{l}\text { One setup for both blocks } \\
\text { due to ocean front. }\end{array}$ \\
\hline B5B $^{b}$ & 8 & 10 & 12 & \\
\hline $\mathrm{C5}$ & 5 & 11 & 14 & \\
\hline $\mathrm{C} 5 \mathrm{~B}^{\mathrm{b}}$ & 9 & 10 & 12 & $\begin{array}{l}\text { The eastern portion of D5 } \\
\text { was surveyed with setup C5B. }\end{array}$ \\
\hline D4 & 8 & 10 & 11 & $\begin{array}{l}\text { The eastern portion of E4 } \\
\text { was surveyed with D4. }\end{array}$ \\
\hline E3 & 7 & 10 & 11 & $\begin{array}{l}\text { The western portion of E4 } \\
\text { was surveyed with E3. }\end{array}$ \\
\hline E5 & 8 & 10 & 12 & $\begin{array}{l}\text { The western portion of D5 } \\
\text { was surveyed with E5. }\end{array}$ \\
\hline E10 & 7 & 10 & 14 & $\begin{array}{l}\text { Anomalous reading due to } \\
\text { system threshold problem. }\end{array}$ \\
\hline E11 & 8 & 10 & 13 & \\
\hline F3 & 6 & 8 & 11 & \\
\hline F5 & 8 & 10 & 12 & \\
\hline F7 & 8 & 9 & 13 & \\
\hline F8 & 7 & 9 & 12 & \\
\hline F9 & 7 & 10 & 12 & \\
\hline $\mathrm{F} 10$ & 8 & 10 & 12 & \\
\hline F11 & 8 & 10 & 12 & \\
\hline
\end{tabular}


Table 4.1. (continued)

\begin{tabular}{|c|c|c|c|c|}
\hline $\begin{array}{l}\text { Block } \\
\text { Number }\end{array}$ & $\underset{\mu \mathbf{R} / \mathbf{h}}{\text { Minimum }}$ & $\begin{array}{l}\text { Mean } \\
\mu \mathrm{R} / \mathrm{h}\end{array}$ & $\begin{array}{l}\text { Marimum } \\
\mu R / h\end{array}$ & Comments \\
\hline $\begin{array}{l}\text { F12 \& } \\
\text { G12 }\end{array}$ & 8 & 10 & 12 & $\begin{array}{l}\text { One setup for both blocks } \\
\text { due to steep hillside. }\end{array}$ \\
\hline G3 & 6 & 8 & 12 & \\
\hline G6 & 8 & 10 & 13 & \\
\hline G7 & 8 & 10 & 12 & \\
\hline $\begin{array}{l}\text { G11 \& } \\
\text { H11 }\end{array}$ & 7 & 10 & 12 & $\begin{array}{l}\text { One setup for both blocks } \\
\text { due to steep hillsides and } \\
\text { thick underbrush. }\end{array}$ \\
\hline H3 & 6 & 8 & 10 & \\
\hline H6 & 7 & 10 & 12 & \\
\hline H7 & 7 & 10 & 12 & \\
\hline H8 & 8 & 10 & 12 & \\
\hline H9 & 8 & 10 & 14 & $\begin{array}{l}\text { Further investigation of } \\
14 \mu R / h \text { area with a walk-on } \\
\text { survey revealed an elevated } \\
\text { region along shale outcrop. }\end{array}$ \\
\hline H12 & 8 & 10 & 12 & \\
\hline H13 & 7 & 10 & 16 & $\begin{array}{l}\text { Located elevated region next } \\
\text { to roadway along shale } \\
\text { outcrop. }\end{array}$ \\
\hline H14 & 8 & 10 & 12 & \\
\hline 12 & $\mathrm{NU}^{*}$ & $N^{2}$ & $N^{2}$ & $\begin{array}{l}\text { A walk-on survey was } \\
\text { performed due to cliff face } \\
\text { and ocean front }(7-12 \mu R / h) \text {. }\end{array}$ \\
\hline I6 & 8 & 10 & 12 & \\
\hline I7 & 8 & 10 & 12 & \\
\hline
\end{tabular}


Table 4.1. (continued)

\begin{tabular}{|c|c|c|c|c|}
\hline $\begin{array}{l}\text { Block } \\
\text { Number }\end{array}$ & $\begin{array}{c}\text { Minimum } \\
\mu \mathrm{R} / \mathrm{h}\end{array}$ & $\begin{array}{l}\text { Mean } \\
\mu R / h\end{array}$ & $\begin{array}{c}\text { Maximum } \\
\mu R / h\end{array}$ & Comments \\
\hline 18 & 8 & 10 & 12 & \\
\hline 19 & 7 & 10 & 12 & \\
\hline I13 & 7 & 9 & 12 & \\
\hline I14 & 8 & 10 & 12 & \\
\hline I15 & $N U^{2}$ & $\mathbf{N U}^{\mathbf{a}}$ & $N U^{a}$ & $\begin{array}{l}\text { A walk-on survey was } \\
\text { performed due to steep } \\
\text { hillside and thick underbrush } \\
(7-12 \mu \mathrm{R} / \mathrm{h}) \text {. }\end{array}$ \\
\hline J1 & $N U^{a}$ & $N U^{a}$ & $N U^{2}$ & $\begin{array}{l}\text { Block } \mathrm{J} 1 \text { no longer existed } \\
\text { due to shoreline erosion. }\end{array}$ \\
\hline $\mathrm{J} 2$ & $N U^{2}$ & $\mathbf{N U}^{\mathbf{a}}$ & $N U^{a}$ & $\begin{array}{l}\text { A walk-on survey was } \\
\text { performed due to cliff face } \\
\text { and ocean front }(7-12 \mu R / h) \text {. }\end{array}$ \\
\hline J6 & 8 & 10 & 12 & \\
\hline J7 & 8 & 10 & 14 & $\begin{array}{l}\text { Anomalous reading due to } \\
\text { system threshold problem. }\end{array}$ \\
\hline J8 & 10 & 10 & 13 & \\
\hline J9 & 7 & 10 & 13 & \\
\hline $\mathrm{J} 13$ & 7 & 10 & 13 & \\
\hline J14 & $N U^{2}$ & $N U^{*}$ & $N^{a}$ & $\begin{array}{l}\text { A walk-on survey was } \\
\text { performed due to steep } \\
\text { hillsides above underground } \\
\text { battery }(10-13 \mu R / \mathrm{h}) \text {. }\end{array}$ \\
\hline J15 & 9 & 11 & 13 & \\
\hline $\mathrm{K} 2$ & $N^{2}$ & $N^{2}$ & $N U^{2}$ & $\begin{array}{l}\text { A walk-on survey was } \\
\text { performed due to cliff face } \\
\text { and ocean front }(7-12 \mu \mathrm{R} / \mathrm{h}) \text {. }\end{array}$ \\
\hline
\end{tabular}


Table 4.1. (continued)

\begin{tabular}{|c|c|c|c|c|}
\hline $\begin{array}{l}\text { Block } \\
\text { Number }\end{array}$ & $\begin{array}{l}\text { Minimum } \\
\mu \mathbf{R} / \mathbf{h}\end{array}$ & $\begin{array}{l}\text { Mean } \\
\mu \mathbf{R} / \mathbf{h}\end{array}$ & $\begin{array}{l}\text { Maximum } \\
\mu \mathbf{R} / \mathbf{h}\end{array}$ & Comments \\
\hline $\mathrm{K} 3$ & 7 & 10 & 12 & \\
\hline K6 & 8 & 10 & 12 & \\
\hline K7 & 7 & 10 & 14 & $\begin{array}{l}\text { The northwestern portion of } \\
\text { L7 was surveyed with } K 7 \text {; } \\
\text { anomalous reading due to } \\
\text { system threshold problem. }\end{array}$ \\
\hline K8 & 8 & 10 & 13 & \\
\hline $\mathrm{K} 9$ & 8 & 10 & 13 & \\
\hline K13 & 7 & 10 & 12 & \\
\hline K14 & 9 & 11 & 13 & $\begin{array}{l}\text { The western portion of the } \\
\text { road through L14 was } \\
\text { surveyed with K14. }\end{array}$ \\
\hline K15 & $N^{2}$ & $N^{2}$ & $\mathrm{NU}^{\mathbf{a}}$ & $\begin{array}{l}\text { A walk-on survey was } \\
\text { performed due to steep } \\
\text { hillsides }(10-13 \mu \mathrm{R} / \mathrm{h}) \text {. }\end{array}$ \\
\hline $\begin{array}{l}\text { L4 \& } \\
\text { L5 }\end{array}$ & 9 & 10 & 13 & $\begin{array}{l}\text { One setup for both blocks } \\
\text { due to cliff face. }\end{array}$ \\
\hline L6 & 7 & 10 & 12 & $\begin{array}{l}\text { The southern portion of L7 } \\
\text { was surveyed with L6. }\end{array}$ \\
\hline L8 & 7 & 10 & 12 & $\begin{array}{l}\text { The northeastern portion of } \\
\text { M8 was surveyed with L8. }\end{array}$ \\
\hline L13 & 8 & 9 & 13 & \\
\hline $\mathrm{L}^{13 B^{b}}$ & 7 & 11 & 15 & $\begin{array}{l}\text { Located elevated region on } \\
\text { steep hillside in sandstone } \\
\text { and shale outcrop. The } \\
\text { southern portion of the road } \\
\text { through L14 was surveyed } \\
\text { with setup L13B. }\end{array}$ \\
\hline M5 & 8 & 10 & 12 & \\
\hline
\end{tabular}


Table 4.1. (continued)

\begin{tabular}{|c|c|c|c|c|}
\hline $\begin{array}{l}\text { Block } \\
\text { Number }\end{array}$ & $\underset{\mu \mathrm{R} / \mathrm{h}}{\text { Minimum }}$ & $\begin{array}{l}\text { Mean } \\
\mu \mathrm{R} / \mathrm{h}\end{array}$ & $\begin{array}{l}\text { Maximum } \\
\mu \mathrm{R} / \mathrm{h}\end{array}$ & Comments \\
\hline M6 & 7 & 10 & 13 & \\
\hline M7 & 6 & 10 & 12 & $\begin{array}{l}\text { The northwestern portion of } \\
\text { M7 was surveyed with N7. } \\
\text { The southern portion of M7 } \\
\text { was surveyed with M6. The } \\
\text { southeastern portion of M8 } \\
\text { was surveyed with M7. The } \\
\text { northwestern portion of L7 } \\
\text { was surveyed with M7. }\end{array}$ \\
\hline M13 & 8 & 11 & 15 & $\begin{array}{l}\text { Located two anomalous } \\
\text { readings. These readings } \\
\text { were not reproducible with a } \\
\text { walk-on survey. }\end{array}$ \\
\hline N5 & 7 & 10 & 12 & \\
\hline N6 & 10 & 12 & 8 & \\
\hline N7 & 7 & 10 & 12 & $\begin{array}{l}\text { The northwestern portion of } \\
\text { N7 was surveyed with P7. } \\
\text { The southern portion of N7 } \\
\text { was surveyed with N6. The } \\
\text { southwestern portion of M8 } \\
\text { was surveyed with N7. }\end{array}$ \\
\hline N8 & 9 & 10 & 12 & $\begin{array}{l}\text { The southeastern portion of } \\
\text { N8 was surveyed with N7. } \\
\text { The northwestern portion of } \\
\text { M8 was surveyed with N8. }\end{array}$ \\
\hline $\mathrm{N} 12$ & 7 & 9 & 11 & \\
\hline N13 & 6 & 10 & 14 & $\begin{array}{l}\text { Located one anomalous } \\
\text { reading that was not } \\
\text { reproducible with a walk-on } \\
\text { survey. }\end{array}$ \\
\hline P7 & 7 & 10 & 12 & \\
\hline P11 & 8 & 9 & 11 & \\
\hline
\end{tabular}


Table 4.1. (continued)

\begin{tabular}{|c|c|c|c|c|}
\hline $\begin{array}{l}\text { Block } \\
\text { Nu:nber }\end{array}$ & $\underset{\mu \mathrm{R} / \mathrm{h}}{\text { Minimum }}$ & $\begin{array}{l}\text { Mean } \\
\mu \mathbf{R} / \mathbf{h}\end{array}$ & $\begin{array}{l}\text { Maximum } \\
\mu R / h\end{array}$ & Comments \\
\hline P12 & 7 & 9 & 12 & \\
\hline Q7 & 7 & 10 & 12 & \\
\hline Q11 & 7 & 9 & 11 & \\
\hline R7A & 8 & 10 & 15 & $\begin{array}{l}\text { Located elevated readings } \\
\text { along cinderblock walls of } \\
\text { Building } 1030 \text {. }\end{array}$ \\
\hline $\mathrm{R}^{-B^{b}}$ & 8 & 10 & 12 & \\
\hline $\begin{array}{l}\text { R10 \& } \\
\text { R11 }\end{array}$ & 7 & 9 & 11 & $\begin{array}{l}\text { One setup for both blocks } \\
\text { due to steep hillside. }\end{array}$ \\
\hline
\end{tabular}

- $\mathrm{NU}=$ no USRADS data collected. Walk-on survey gamma radiation exposure rate ranges are provided under comments.

b Two USRADS setups were required for this block. 
The error was found to be an electronic threshold drifting problem related to intermittent inadequate charging of equipment. All data were scanned, and only the blocks in question exhibited the problem. The problem was fixed. These blorks were determined to be within the background threshold as confirmed by the walk-on surveys with the scintillometer.

USRADS provided the real-time survey coverige, data evaluation, and graphics generation in the field while the ORNL/PAG crew was mobilized on the site. The system facilitated verification of survey coverage, and highlighted and electronically stored all data points above a threshold of $5500 \mathrm{cpm}$. All White Point USRADS data have been stoce on disk and can be viewed and manipulated without returning to the site. The data have been input onto an automated computer aided drafting map that gives a total site view with the associated survey coverage (Plate 3).

\section{INDOOR RADIATION INVESTIGATION}

\subsection{DESCRIPTTON}

Indoor radiation surveys were performed in four buildings at White Point.

Building 1026 was once the Nike Missile Warheading Area. This building is $73 \mathrm{~m}^{2}$ (787 $\mathrm{ft}^{2}$ ), with a concrete floor and cinder-block walls. It consists of one large room with garage doors at the east and west ends (Fig. 5.1). This building, like all of the buildings at White Point, has been heavily vandalized. All windows were broken, doors torn off the hinges, and panels broken out. The floor was littered with building materials. In order to survey this building, ail building materials were stored at the south end of the building, making a small portion of the floor inaccessible. 

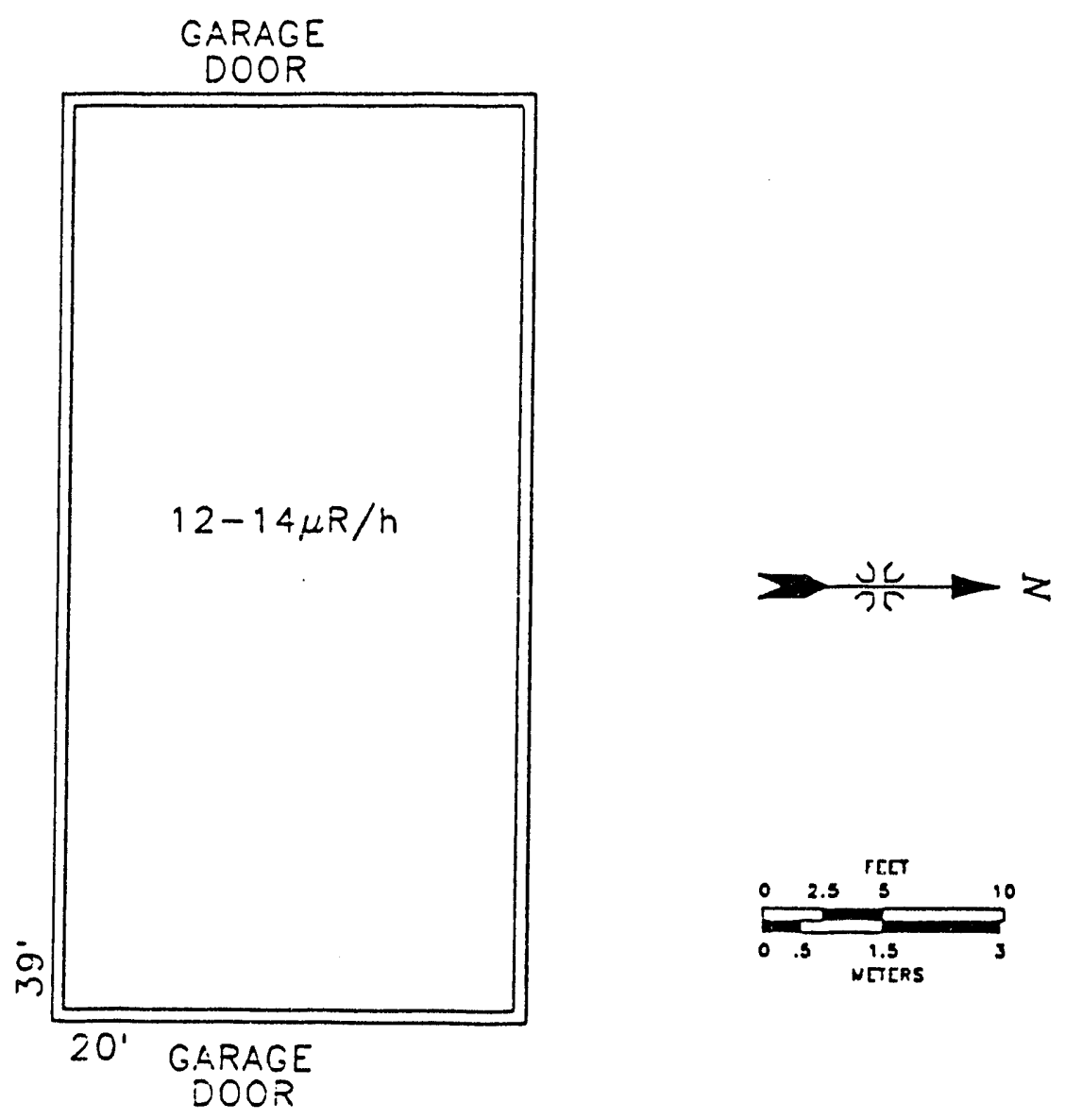

SWS/GKS $7 / 28 / 81$

Fig. 5.1. White Point Nike Missile Site, Building 1026. 
Building 1027 was once the Nike Missile Assembly and Test Area. This building is $146 \mathrm{~m}^{2}\left(1,573 \mathrm{ft}^{2}\right)$ and has a concrete floor and cinder-block walls. It consists of five rooms: garage, kitchen, bathroom, furnace room, and another room designated miscellaneous (Fig. 5.2). All windows were broken and the doors heavily damaged. The southwest corner of the garage was inaccessible due to stacks of building materials. The park service is in the process of renovating this building for use as living quarters for a park ranger.

Buildings 1019 and 1020 are underground missile silos. These identical buildings are each $360 \mathrm{~m}^{2}\left(3,873 \mathrm{ft}^{2}\right)$ and have concrete floors and walls. Each silo consists of a large room with a hydraulic elevator in the center of the room that extends the length of the room. There is an area underneath the elevator approximately the length and width of the elevator and about three feet high. A hallway in the southeast corner leads to a vault room with an attached escape-hatch area. The entrance and stairway to the silo are also located at the southeast corner (Fig. 5.3 and 5.4).

Safety was a primary concern while surveying these silos. A preliminary inspection of the west silo was performed by the health and safety officer (HSO), of the ORNL/PAG team and a policeman from Los Angeles Air Force Base. They entered from a 4- $\mathrm{ft}^{2}$ opening down a built-in ladder located in the northcentral area next to the hydraulic housing. A combustible gas indicator (CGI) and protective clothing were used as precautionary measures. They determined that there had been recent entry by unauthorized personnel. A welder was employed to cut the stairway doors open and weld hasps to lock these doors at night. In addition, all other entrances were welded shut to secure the area from any further vandalism and unauthorized entrance. Base police entered the silo again before the survey team began work. Survey personnel worked in teams of two, with frequent visits by other staff. A CGI accompanied all personnel entering the silo.

A hydraulic-fluid spill covered a large portion of the floor in the west silo. A photoionization detector was used to investigate this spill, and samples were taken and sent to a lab for polychlorinated biphenyl (PCB) analysis. Radiologic readings were not taken in grid blocks contaminated by the spill. 


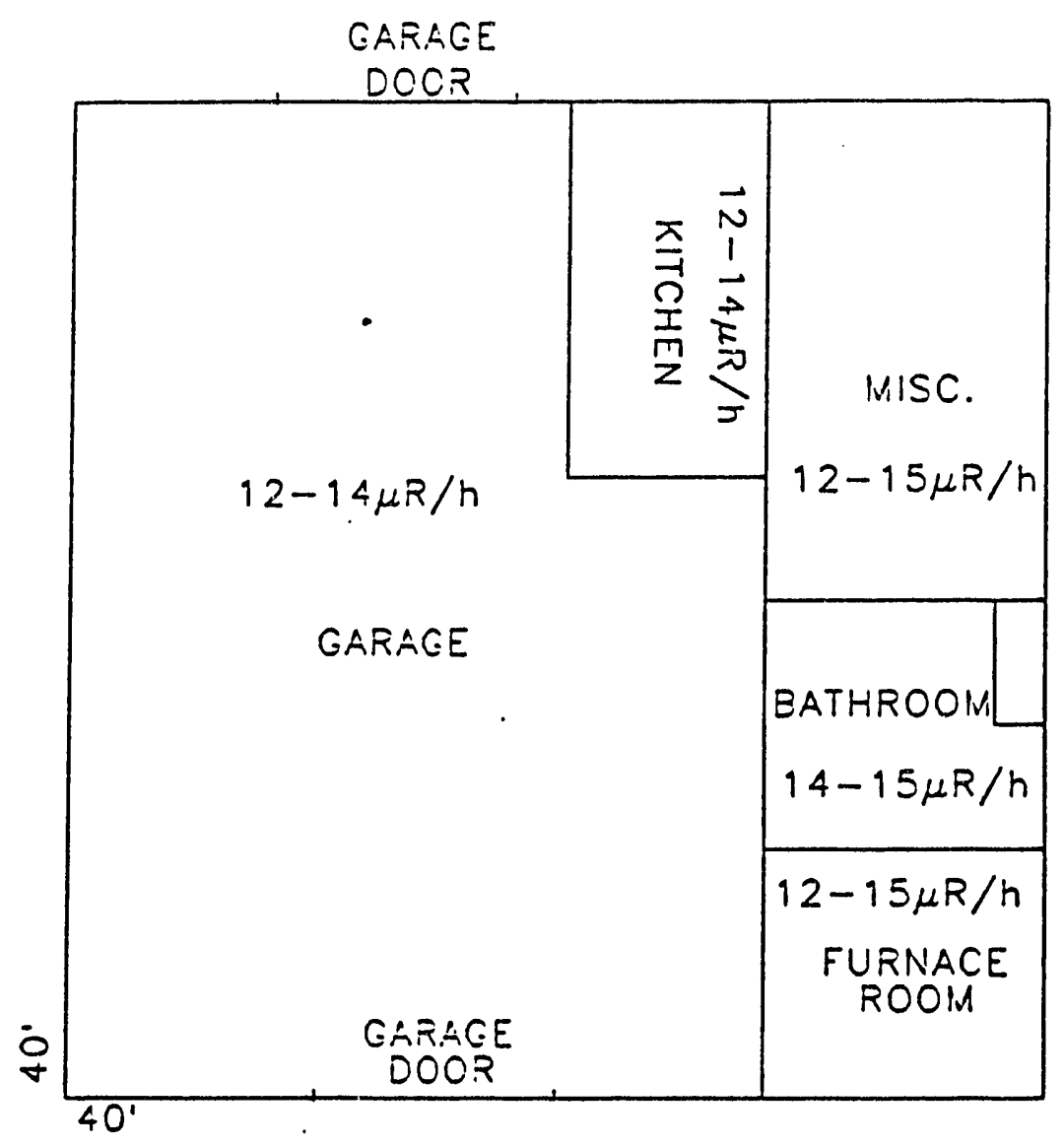

Fig. 5.2. White Point Nike Missile Sitè, 战

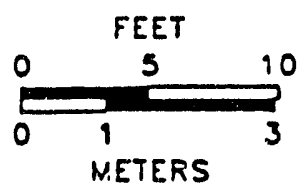
Building 1027 . 


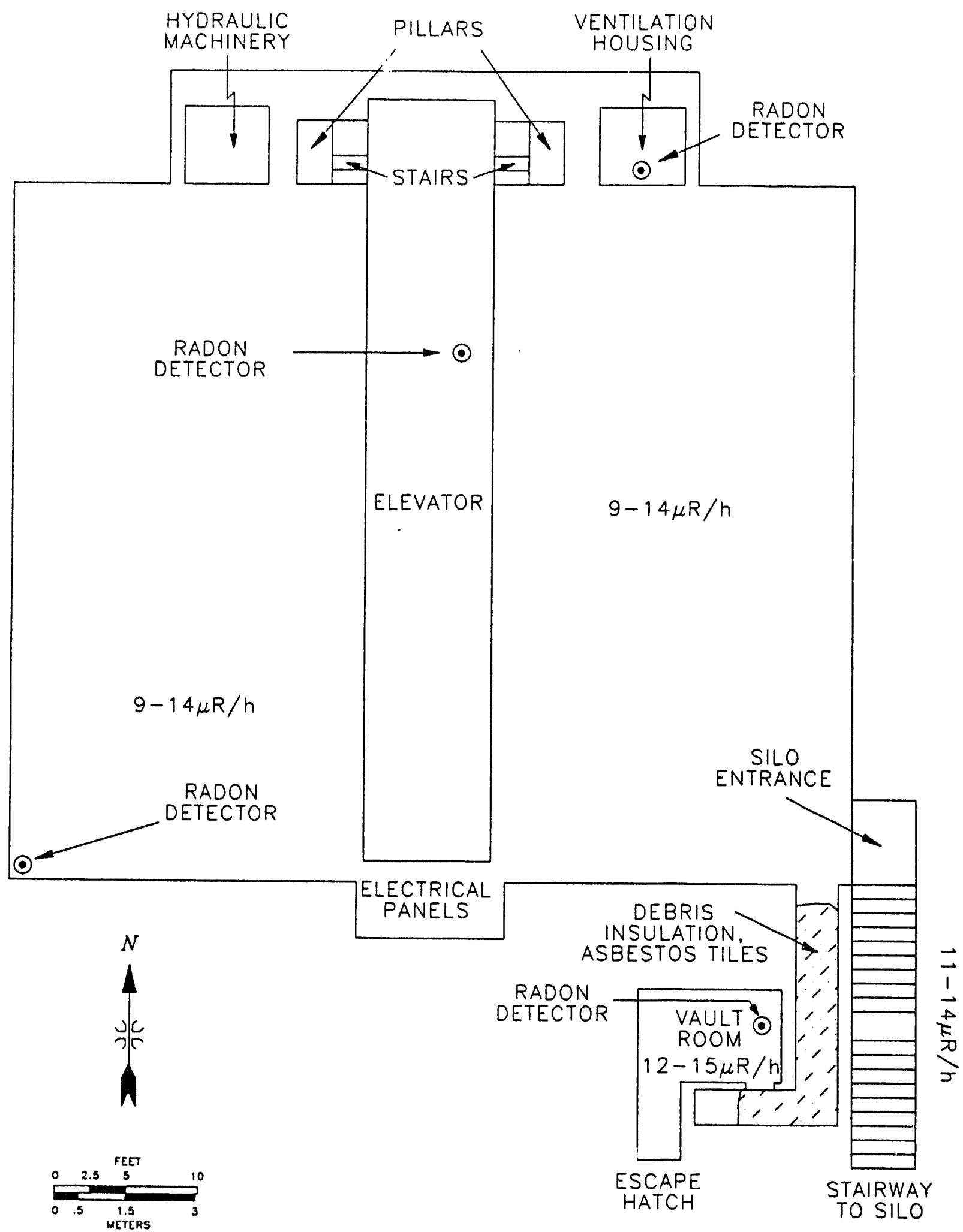

Fig. 5.3. White Point Nike Missile Site, Building 1012, east silo. 


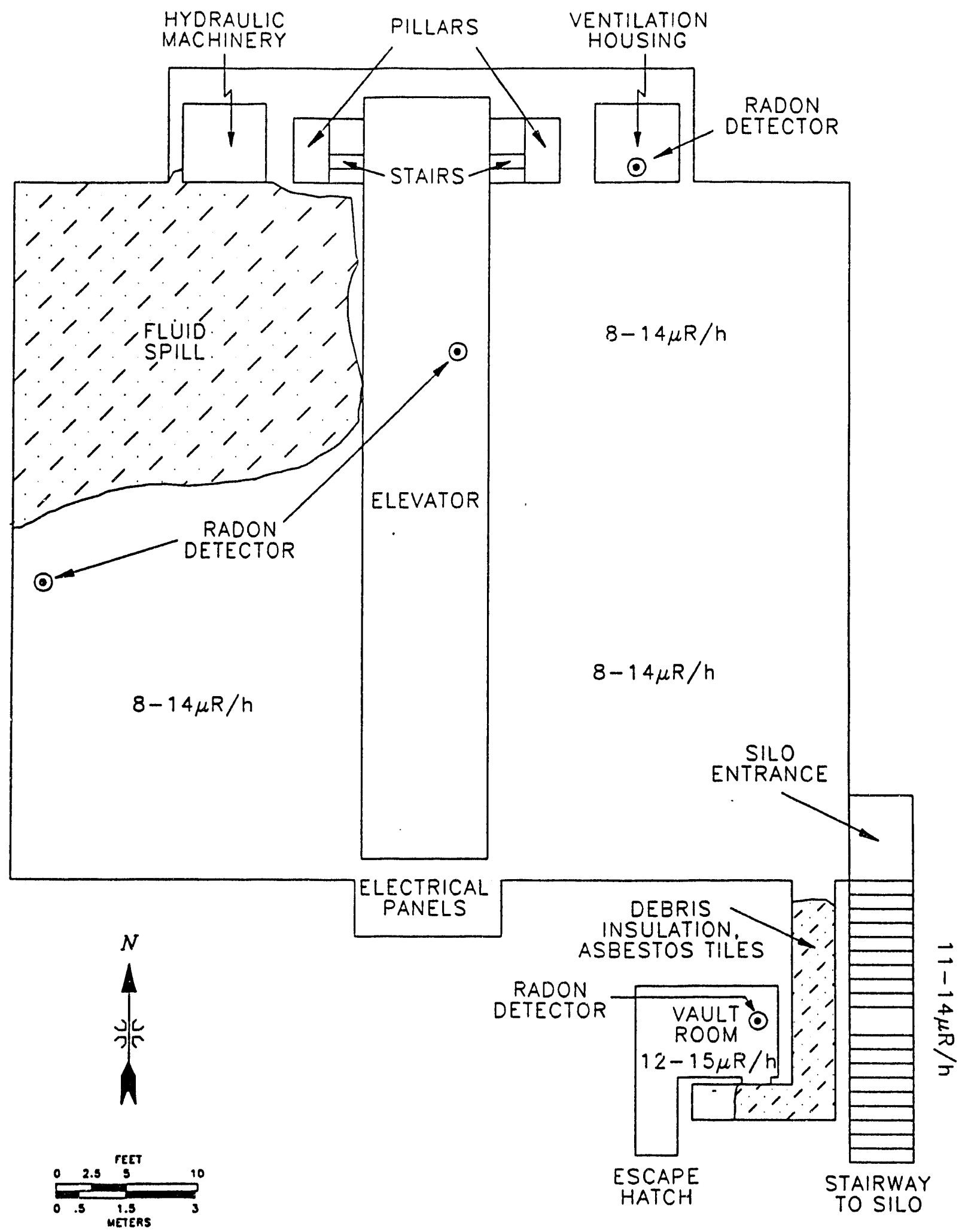

Fig. 5.4. White Point Nike Missile Site, Building 1020, west stlo. 
The HSO and another team member entered the area underneath the elevator at the north end of the east silo. After investigation and confirmation of six concrete jacks securing the position of the elevator, it was decided that three survey members would take a limited number of readings and smears. Protective clothing, gloves, and dust masks were worn by all team members.

Another potential hazard in the east silo was contamination from asbestos. The hallway leading to the vault area was littered with insulation and wall tile. Since construction of the silo took place in 1954, there was potential that these materials contained asbestos. After discussion with the Radiation Projects Manager, the HSO decided that a survey of the hallway leading to the vault and escape hatch would not be done. In addition, any personnel entering the hallway to access the vault and escape hatch would wear protective clothing, including Tyvek suits, gloves, and full-face respirators with asbestos filters. A limited survey was performed by two team members in the vault room and escape hatch after the hallway floor was covered with plastic. This survey team also took samples of the insulation and wall tile for asbestos analysis.

\subsection{INDOOR SURVEY METHODS AND PROCEDURES}

A Bicron ${ }^{\mathrm{m}}$ Analyst ratemeter and alpha probe were used for alpha radiation measurements, a Ludlum ratemeter and Geiger-Muller pancake probe were used for beta-gamma radiation measurements, and a Victoreen portable gamma radiation scintillometer was used for gamma radiation measurements. Operational checks performed each day to ensure performance of all instruments were recorded in the logbook. These checks consisted of a battery check, a background reading, and a reading using a check source. Instruments were not used if the check values fell outside of the 3-sigma or 5\% error range indicated on the electronics laboratory calibration tag on the instrument.

Building interiors were divided into $2 \times 2 \mathrm{~m}$ grids. Each grid block was assigned a designated block name and five reading points were marked $0.5 \mathrm{~m}$ from each corner and in the center of each block. In each building, the floors and 2-m 
high on each wall were surveyed. Reading points in partial grid blocks had to be adjusted.

A general gamma radiation survey was performed on the floor of each room. One-min direct measurements were taken at all five points in each grid, and results were recorded on Surface Contamination Survey forms (ORNL 1991b, Procedure TE-025). Additional measurements were taken in areas of suspected contamination and noted on the Surface Contamination Survey forms. In addition, the following information was also recorded on the forms: White Point, building number and room, block name, date measurements were taken, surveyor's initials, and instrument identification numbers.

In order to report data that are comparable to release criteria, all alpha and beta-gamma radiation survey results were converted from cpm to $\mathrm{dpm}$ using the following formula:

$$
\begin{aligned}
& \text { dpm/100 } \mathrm{cm}^{2}=\frac{N}{T \times E \times G} \\
& \text { where } \\
& \qquad \begin{aligned}
\mathrm{N} & =\text { net counts } \\
\mathrm{T} & =\text { count time, } \mathrm{min} \\
\mathrm{E} & =\text { detector efficiency, counts per disintegrations } \\
\mathrm{G} & =\text { probe area, } \mathrm{cm}^{2} \text { divided by } 100 .
\end{aligned}
\end{aligned}
$$

A determination of removable alpha and beta-gamma radiation contamination on equipment and building surfaces was performed. Smears evere taken in at least $10 \%$ of the grid blocks at the highest alpha radiation readings as determined by direct measurements. An area of approximately $100 \mathrm{~cm}^{2}$ was smeared, and the smear placed in a protective covering. All smears were given a smear number, location, date, and surveyor's initials. Smears were counted with a Ludlum 2929 dual scaler or proportional counter with at least a 4-h delay to permit decay of short-lived radionuclides. 
Alpha and beta-gamma radiation smear results were converted from $\mathrm{cpm}$ to dpm using the following formula:

$$
\begin{aligned}
& \text { dpm/100 } \mathrm{cm}^{2}=\frac{\mathrm{N}}{\mathrm{T} \times \mathrm{E}} \\
& \text { where } \\
& \qquad \begin{aligned}
\mathrm{N} & =\text { net counts } \\
\mathrm{T} & =\text { count time, min } \\
\mathrm{E} & =\text { detector efficiency, counts per disintegrations }
\end{aligned}
\end{aligned}
$$

Guidelines used to interpret these findings are shown in Table 5.1, Surface Radioactivity Guides, as described in DOE Order 5480.11 (U.S.DOE 1990a).

\subsection{INDOOR SURVEY RESULTS}

The general gamma radiation exposure rates for each building are shown on Figs. 5.1, 5.2, 5.3, and 5.4. All gamma radiation readings were within the background range of 8 to $15 \mu \mathrm{R} / \mathrm{h}$.

A summary of the results is presented in Table 5.2. This summary is compiled from all Surface Contamination Survey sheets with conversion of $\mathrm{cpm}$ to $\mathrm{dpm} / 100 \mathrm{~cm}^{2}$. One alpha radiation and four gamma radiation readings exceeded the guidelines presented in Table 5.1. These readings were under the elevator in the west silo. Readings of smears taken at this same location fell below guidelines.

Slightly elevated readings in Buildings 1026 and 1027 may be attributed to the cinder blocks used in the construction of these buildings. Elevated readings found in Buildings 1019 and 1020 are believed to be due to radon daughters associated with radon gas. Radon daughter concentration (RDC) detectors were placed in both silos to determine working level concentrations of radon daughters. The locations of these detectors are shown on Figs. 5.3 and 5.4 and designated by RDC. Fort MacArthur personnel were alerted to the detector placement and indicated that they would remove the detectors when the six month test period 
Table 5.1 Surface Radioactivity Guides

DOE Order $5480.11 \quad 7-20-89$

\begin{tabular}{|c|c|c|}
\hline Nuclide $^{\text {I/ }}$ & Removable $^{2 / 4}$ & $\begin{array}{c}\text { Total }{ }^{2 / 2} \\
\text { (Fired plus Removable) }\end{array}$ \\
\hline $\begin{array}{l}\mathrm{U} \text {-nat, }{ }^{235} \mathrm{U},{ }^{238} \mathrm{U} \text {, and } \\
\text { associated decay products }\end{array}$ & $\begin{array}{c}1,000 \mathrm{dpm} \text { alpha/ } \\
100 \mathrm{~cm}^{2}\end{array}$ & $5,000 \mathrm{dpm}$ alpha $/ 100 \mathrm{~cm}^{2}$ \\
\hline 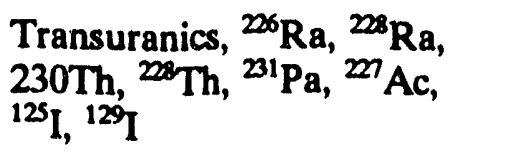 & $20 \mathrm{dpm} / 100 \mathrm{~cm}^{2}$ & $300 \mathrm{dpm} / 100 \mathrm{~cm}^{2}$ \\
\hline $\begin{array}{l}\text { Th-nat, }{ }^{232} \mathrm{Th},{ }^{90} \mathrm{Sr},{ }^{203} \mathrm{Ra} \text {, } \\
{ }^{24} \mathrm{Ra},{ }^{232} \mathrm{U},{ }^{126} \mathrm{I},{ }^{131} \mathrm{I},{ }^{133} \mathrm{I}\end{array}$ & $200 \mathrm{dpm} / 100 \mathrm{~cm}^{2}$ & $1,000 \mathrm{dpm} / 100 \mathrm{~cm}^{2}$ \\
\hline $\begin{array}{l}\text { Beta-gamma emitters } \\
\text { (nuclides with decay modes } \\
\text { other than alpha emission or } \\
\text { spontaneous fission) except } \\
{ }^{\circ} \mathrm{Sr} \text { and others noted above. }\end{array}$ & $\begin{array}{l}1,000 \text { dpm beta- } \\
\text { gamma } / 100 \mathrm{~cm}^{2}\end{array}$ & $\begin{array}{l}5,000 \mathrm{dpm} \text { beta- } \\
\text { gamma } / 100 \mathrm{~cm}^{2}\end{array}$ \\
\hline
\end{tabular}

1) Where surface contamination by both alpha- and beta-gamma-emitting nuclides exists, the limits established for alpha- and beta-gamma-emitting nuclides should apply independently.

21 As used in this table, dpm (disintegrations per minute) means the rate of emissions by radioactive material as determined by correcting the counts per minute observed by an appropriate detector for background, efficiency, and geometric factors ascociated with the instrumentation.

3/ The levels may be averaged over one square meter provided the maximum surface activity in any area of $100 \mathrm{~cm}^{2}$ is less than three times the guide values. For purposes of averaging, any square meter of surface shall be considered to be above the activity guide $G$ if: (1) from measurements of representative number $n$ of sections it is determined that $1 / n \sum_{n} S_{i} \geq G$, where $S_{i}$ is the dis/min-100 $\mathrm{cm}^{2}$ determined from measurement of section $i$; or (2) it is determined that the sum of the activity of all isolated spots or particles in any $100 \mathrm{~cm}^{2}$ area exceeds $3 \mathrm{G}$. 
Table 5.1 (continued)

4/ The amount of removable radioactive material per $100 \mathrm{~cm}^{2}$ of surface area should be determined wiping that area with dry filter or soft absorbent paper, applying moderate pressure, and assessing the amount of radioactive material on the wipe with an appropriate instrument with know efficiency. (Note - The use of dry material may not be appropriate for tritium). When removable contamination on objects of surface area less than $100 \mathrm{~cm}^{2}$ is determined, the activity per unit area should be based on actual area and the entire area should be wiped. Except for transuranics and ${ }^{206} \mathrm{Ra},{ }^{228} \mathrm{Ra},{ }^{227} \mathrm{Ac},{ }^{228} \mathrm{Th},{ }^{230} \mathrm{Th}$, and ${ }^{231} \mathrm{~Pa}$ alpha emitters, it is not necessary to use wiping techniques to measure removable contamination levels if direct scan surveys indicate that the total residual surface contamination levels are within the limits for removable contamination.

5/ This category of radionuclides includes mixed fission products, including ${ }^{90} \mathrm{Sr}$ which is present in them. It does not apply to ${ }^{90} \mathrm{Sr}$ which has been separated from the other fission products or mixtures where the ${ }^{90} \mathrm{Sr}$ has been enriched. 
Table 5.2. Results of interior survey direct readings

\begin{tabular}{|c|c|c|c|c|}
\hline & \multicolumn{2}{|c|}{ Alpha Radiation } & \multicolumn{2}{|c|}{ Beta-Gamma Radiation } \\
\hline & $\begin{array}{c}\text { High, } \\
\operatorname{dpm} / 100 \mathrm{~cm}^{2}\end{array}$ & $\begin{array}{c}\text { Low, } \\
\operatorname{dpm} / 100 \mathrm{~cm}^{2}\end{array}$ & $\begin{array}{c}\text { High, } \\
\operatorname{dpm} / 100 \mathrm{~cm}^{2}\end{array}$ & $\begin{array}{c}\text { Low, } \\
\operatorname{dpm} / 100 \mathrm{~cm}^{2}\end{array}$ \\
\hline \multicolumn{5}{|c|}{ Building 1020, West Silo } \\
\hline $\begin{array}{l}\text { Elevator } \\
\text { Vault room, esc. hatch } \\
\text { Stairwell } \\
\text { Equipment, pillars } \\
\text { N. wall } \\
\text { S. wall } \\
\text { W. wall } \\
\text { E. wall } \\
\text { Floor }\end{array}$ & $\begin{array}{c}1440 \\
251 \\
96 \\
996 \\
76 \\
91 \\
68 \\
84 \\
192\end{array}$ & $\begin{array}{c}108 \\
5 \\
\text { bkgd } \\
32 \\
\text { bkgd } \\
5 \\
8 \\
8 \\
\text { bkgd }\end{array}$ & $\begin{array}{c}11120^{*} \\
1989 \\
2634 \\
764 \\
1129 \\
1935 \\
1022 \\
1237 \\
1678\end{array}$ & $\begin{array}{l}2675 \\
\text { bkgd } \\
\text { bkgd } \\
\text { bkgd } \\
\text { bkgd } \\
\text { bkgd } \\
\text { bkgd } \\
\text { bkgd } \\
\text { bkgd }\end{array}$ \\
\hline \multicolumn{5}{|c|}{ Building 1019, East Silo } \\
\hline $\begin{array}{l}\text { Elevator } \\
\text { Vault room, esc. hatch } \\
\text { Stairwell } \\
\text { Equipment, pillars } \\
\text { N. wall } \\
\text { S. wall } \\
\text { W. wall } \\
\text { E. wall } \\
\text { Floor }\end{array}$ & $\begin{array}{r}1397 \\
164 \\
144 \\
365 \\
132 \\
156 \\
144 \\
114 \\
388\end{array}$ & $\begin{array}{c}123 \\
55 \\
\text { bkgd } \\
20 \\
20 \\
16 \\
32 \\
4 \\
\text { bkgd }\end{array}$ & $\begin{array}{l}3095 \\
2937 \\
2581 \\
2742 \\
2366 \\
2419 \\
2688 \\
2366 \\
3777\end{array}$ & $\begin{array}{r}1574 \\
\text { bkgd } \\
430 \\
\text { bkgd } \\
367 \\
\text { bkgd } \\
\text { bkgd } \\
\text { bkgd } \\
\text { bkgd }\end{array}$ \\
\hline \multicolumn{5}{|c|}{ Building 1026} \\
\hline $\begin{array}{l}\text { Floors } \\
\text { Walls }\end{array}$ & $\begin{array}{r}75 \\
104\end{array}$ & $\begin{array}{l}\text { bkgd } \\
\text { bkgd }\end{array}$ & $\begin{array}{l}2465 \\
2675\end{array}$ & $\begin{array}{l}\text { bkgd } \\
\text { bkgd }\end{array}$ \\
\hline \multicolumn{5}{|c|}{ Building 1027} \\
\hline $\begin{array}{l}\text { Garage floor } \\
\text { Garage walls } \\
\text { Furnace room } \\
\text { Kitchen } \\
\text { Bathroom } \\
\text { Miscellaneous }\end{array}$ & $\begin{array}{r}66 \\
146 \\
83 \\
90 \\
80 \\
139\end{array}$ & $\begin{array}{l}\text { bkgd } \\
\text { bkgd } \\
\text { bkgd } \\
\text { bkgd } \\
\text { bkgd } \\
\text { bkgd }\end{array}$ & $\begin{array}{l}4616 \\
2465 \\
2570 \\
1667 \\
3548 \\
2634\end{array}$ & $\begin{array}{l}484 \\
\text { bkgd } \\
\text { bkgd } \\
\text { bkgd } \\
\text { bkgd } \\
\text { bkgd }\end{array}$ \\
\hline
\end{tabular}

* All four readings above background were in this area. bkgd $=$ readings at or below the background reading. 
ended and send the exposed detectors to ORNL/PAG. When Fort MacArthur personnel entered the silos to retrieve the detectors, no detectors could be located indicating possible vandalism sometime during the test period. Therefore, no radon data were collected for the silos.

Elevated readings were found in the silos in areas of low ventilation. In general, higher readings were found in the east silo where less ventilation exists. The silos exhibited higher readings under the elevators, which have almost no ventilation. Higher readings in the west silo were located in the vault and escape hatch, which have very little ventilation. Higher readings were also found associated with the vent housing grates. This may be explained by the attachment of radon daughters to ambient aerosols and deposition on the surface of the vent. Buildup may occur in circulating systems due to the high volume of air. Deposition most likely occurred on the metal equipment and screens in the silos due to charged particles associated with radon daughters. Higher readings were also associated with drains and underground pipes. These may be escape routes for radon gas from underground rock and soil. It should be noted that all smears had readings at or slightly above background after the 4-h delay in reading. Radon daughters have very short half lives (NCRP 1988).

Results of smears are presented in Table 5.3. All readings were well below the guidelines presented in Table 5.1.

\subsection{DISCUSSION}

Complete scans of Buildings 1019, 1020, 1026, and 1027 were performed where feasible as discussed above. All procedures conformed with the draft work plan (HAZWRAP 1990a). Analysis of results in these buildings revealed only four readings above the guidelines shown in Table 5.1. Analysis of hydraulic fluid in the west silo revealed no PCB levels above guidelines. Analysis revealed no asbestos fibers in the insulation; however, the tile did contain asbestos. 
Table 5.3. Interior survey smear results

\begin{tabular}{lcccc}
\hline & Direct Probe & Smear & Sipha, \\
Smear \# & Location & $\begin{array}{c}\text { Alpha, } \\
\text { dpm/100 cm }\end{array}$ & $\begin{array}{c}\text { Smear } \\
\text { Bpm/100 cm }\end{array}$ & $\begin{array}{c}\text { Beta-Gamma, } \\
\text { dpm/100 cm }\end{array}$ \\
\hline
\end{tabular}

Building 1027

\begin{tabular}{|c|c|c|c|c|}
\hline 1 & Block EE-A Garage & 117 & 3 & bkgd \\
\hline 2 & Block K-A Misc & 124 & bkgd & bkgd \\
\hline 3 & Block DD-E Garage & 139 & bkgd & bkgd \\
\hline 4 & Block CC-A Garage & 139 & 5 & bkgd \\
\hline 5 & Block L-A Misc & 139 & bkgd & bkg \\
\hline 6 & Block J-A Misc & 131 & bkgd & bkg \\
\hline 7 & Block I-C Misc & 139 & 5 & bkg \\
\hline 8 & Block H-A Misc & 131 & bkgd & 0.0 \\
\hline 9 & Block G-D Misc & 131 & bkgd & bkgd \\
\hline 10 & Block FF-E Garage & 146 & 5 & 1 \\
\hline 16 & Kitchen duct & NT & bkgd & \\
\hline
\end{tabular}

Building 1019

$\begin{array}{llccc}17 & \text { Under elevator } & 260 & \text { bkgd } & 0.03 \\ 18 & \text { Under elevator } & 123 & \text { bkgd } & 0.07 \\ 19 & \text { Under elevator } & 452 & \text { bkgd } & 0.03 \\ 20 & \text { Under elevator } & 1397 & \text { bkgd } & 0.45 \\ 27 & \text { Block II-D Floor } & 201 & 5 & 0.21 \\ 28 & \text { Block PP Floor } & 388 & \text { bkgd } & 0.31 \\ 29 & \text { Block YY-D Floor } & 279 & \text { bkgd } & \text { bkgd } \\ 30 & \text { Block CCC-C Floor } & 196 & 8 & 0.35 \\ 31 & \text { Block HHH-D Floor } & 247 & \text { bkgd } & \text { bkgd } \\ 32 & \text { Block LLL-A Floor } & 180 & \text { bkgd } & 0.49 \\ 33 & \text { Block PPP-C Floor } & 224 & \text { bkgd } & 0.56 \\ 34 & \text { Block QQQ-C Floor } & 210 & \text { bkgd } & \text { bkgd } \\ 35 & \text { Block RRR-C Floor } & 188 & 3 & 0.31 \\ 36 & \text { Block WWW-A Floor } & 160 & \text { bkgd } & 0.38 \\ 37 & \text { Block ZZZ-A Floor } & 164 & \text { bkgd } & \text { bkgd } \\ 38 & \text { Block S1-B S. Wall } & 152 & \text { bkgd } & 0.28 \\ 39 & \text { Block S3-E S. Wall } & 156 & \text { bkgd } & \text { bkgd } \\ 40 & \text { Block SW4-A Stairway } & 144 & \text { bkgd } & 0.03 \\ 41 & \text { Vent housing-grate } & 365 & 5 & 0.49 \\ 42 & \text { S.screen-W.side A } & 224 & 3 & 0.35 \\ 43 & \text { N.screen-E.side } & 329 & \text { bkgd } & \text { bkgd } \\ 44 & \text { N.screen-W.side A } & 296 & 3 & \text { bkgd } \\ 45 A & \text { Vault-Block 2-B } & 164 & \text { bkgd } & 0.31\end{array}$


Table 5.3. (continued)

\begin{tabular}{lccc}
\hline & $\begin{array}{c}\text { Direct Probe } \\
\text { Alpha, }\end{array}$ & $\begin{array}{c}\text { Smear } \\
\text { Alpha, } \\
\text { Smear * }\end{array}$ & $\begin{array}{c}\text { Smear } \\
\text { Lom }\end{array}$ \\
\hline
\end{tabular}

Building 1026

$\begin{array}{llccr}11 & \text { Block HH-A } & 88 & \text { bkgd } & 0.10 \\ 12 & \text { Block BB-B } & 92 & \text { bkgd } & \text { bkgd } \\ 13 & \text { Block AA-E } & 104 & \text { bkgd } & 0.07 \\ 14 & \text { Block Z-A } & 80 & \text { bkgd } & 0.10\end{array}$

Building 1020

\begin{tabular}{|c|c|c|c|c|}
\hline 21 & U.ıder elevator & 224 & bkgd & 0.35 \\
\hline 22 & Under elevator & 324 & bkgd & bkgd \\
\hline 23 & Under elevator & 592 & 5 & 0.21 \\
\hline 24 & Under elevator & 360 & bkgd & 0.28 \\
\hline 25 & Under elevator & 472 & bkgd & bkgd \\
\hline 26 & Under elevator & 1440 & 3 & bkgd \\
\hline 45B & Block E1-B E. wall & 84 & bkgd & bkgd \\
\hline 46 & Block J-E Floor & 64 & bkgd & 0.28 \\
\hline 47 & Block II-Floor drain & 192 & bikgd & 0.14 \\
\hline 48 & Block SW3-A Stairway & 59 & bkgd & bkgd \\
\hline 49 & Vent housing-grate & 996 & 3 & 0.31 \\
\hline 50 & Vent housing-W.side B & 168 & bkgd & bkgd \\
\hline 51 & E.pillar-E.side A & 116 & bkgd & 0.17 \\
\hline 52 & E.pillar-W.side A & 168 & bkgd & 0.14 \\
\hline 53 & W.pillar-E.side A & 128 & bkgd & 0.24 \\
\hline 54 & W.pillar-W.side A & 130 & bkgd & bkgd \\
\hline 55 & S.screen-E.side D & 333 & bkgd & 0.28 \\
\hline 56 & S.screen-W.side A & 288 & 3 & 0.31 \\
\hline 57 & Hyd. housing-front $A$ & 132 & bkgd & bkgd \\
\hline 58 & Hyd. housing-E.side A & 151 & bkgd & bkgd \\
\hline 59 & N.screen-W.side D & 348 & bkgd & 0.38 \\
\hline 60 & N.screen-E.side A & 304 & bkgd & 0.14 \\
\hline 61 & Vault-Block 1-E & 242 & bkgd & bkgd \\
\hline 62 & Vault-Block 2-B & 251 & 3 & 0.10 \\
\hline 63 & Valut-Block 3-A & 146 & bkgd & bkgd \\
\hline 64 & Vault-Block 4-B & 192 & bkgd & bkgd \\
\hline 65 & Vault-Block 5-B & 187 & bkgd & bkgd \\
\hline 66 & Vault-Block 6-A & 219 & bkgd & 0.45 \\
\hline 67 & Esc. hatch-E.wall A & 146 & bkgd & 0.38 \\
\hline
\end{tabular}

bkgd = readings at or below the background reading. $\hat{i}, \hat{i}=$ no reading taken. 


\section{SUMMARY AND CONCLUSIONS}

A background radiation investigation of the region was performed so that gamma radiation counts could be converted to exposure rates. In order to determine background levels for soil in the area, five surface and five subsurface samples were taken at the South Shores School. Alpha and beta-gamma radiation measurements were also taken on and off site.

Of the grid blocks chosen for survey by USRADS, two blocks could not be surveyed because of shore line erosion. When not accessible by USRADS or to verify anomalous measurements, portions of some blocks were surveyed using walk-on surveys with gamma scintillometers. All measurements were within background gamma radiation limits for the area except for eight anomalous readings.

One of the regions was associated with naturally occurring radiation inherent in the cinder blocks of Building 1030. Soil samples were taken at three of the anomalous regions associated with a uranium-bearing shale outcrop. Results from these regions were elevated. Data in the other four blocks exhibited drifting threshold problems that were corrected. Walk-on radiological surveys showed no anomalous measurements in these blocks; therefore, they were not sampled.

Research by the USGS indicates that the Monterey Formation present on the site contains above normal levels of uranium (USGS 1987). The anomalies are most likely due to localized $L$ anium deposits in the Altamira Shale Member of the Monterey Formation. The areas of the anomalous readings are not in the vicinity of the silos and buildings where the Nike missiles were handled. Soil sample results show that the radionuclides present are from naturally occurring uranium in equilibrium and are not associated with missile handling or dismantling. 
Alpha, beta-gamma, and gamma radiation surveys were performed at predetermined coordinates in 83 of the 85 blocks. Soil samples were taken at ten predetermined locations. All exterior alpha, beta-gamma and gamma radiation survey readings fell below the guidelines outlined in DOE Order 5480.11 (DOE 1990a). Soil sample results from the 10 predetermined locations fell within the range of the background samples taken at the South Shores School.

Buildings 1026 and 1027 and the two missile silos (Buildings 1019 and 1020) were characterized on the floors and walls. Four slightly elevated readings were detected in the west silo. These anomalous exposure rates were most likely due to a buildup of natural radon, indicative of an underground, poorly ventilated, concrete structure (NCRP 1988). All other indoor measurements were found to be below the guidelines used in DOE Order 5480.11 (DOE 1990a). Radon detectors were placed at the time of survey but were not present at the time of retrieval; therefore, no radon data could be reported.

The reconnaissance radiation survey conducted by the ORNL/PAG Grand Junction office at the White Point Nike Missile Site showed no indication of elevated, man-made radiation exposure rates due to past DOD operations. The elevated soil sample results and indoor measurements are attributed to naturally occurring radiation. 
REFERENCES 


\section{REFERENCES}

Berven, B. A., C. A. Little, and M. S. Blair. 1991. A method to automate radiological surveys: The Ultrasonic Ranging and Data System. Health Physics, 60(3):367-373.

HAZWRAP. 1990a. Work Plan for Site Investigation at White Point, San Pedro, California. Draft. Prepared by IT Corporation for Hazardous Waste Remedial Actions Program, Oak Ridge, Tenn.

HAZWRAP. 1990b. Quality Control Requirements for Field Methods. DOE/HWP-69/R1. Hazardous Waste Remedial Actions Program, Oak Ridge, Tenn.

HAZWRAP. 1990c. Requirements for Quality Control of Analytical Data. DOE/HWP-65/R1. Hazardous Waste Remedial Actions Program, Oak Ridge, Tenn.

NCRP. 1988. Measurement of Radon and Radon Daughters in Air. NCRP Report No. 97. National Council on Radiation Protection.

ORNL. 1991a. Work Plan for Site Investigation at White Point, San Pedro, California. Draft addendum. Oak Ridge National Laboratory, Grand Junction, Colo.

ORNL. 1991b. Pollutant Assessments Group Procedures Manual. ORNL-6645. Oak Ridge National Laboratory, Grand Junction, Colo. 
U.S.DOE. 1990a. Radiation Protection for the Occupational Worker. DOE Order 5480.11. U. S. Department of Energy.

U.S.DOI. 1946. Geology and Paleontology of Palos Verdes Hills Califomia. Professional Paper 207. U. S. Department of the Interior.

USGS. 1987. Uranium in the Monterey Formation of California. Bulletin 1581-A. U. S. Geological Survey, Reston, Va. 


\section{ACRONYMS AND INITIALISMS}

$\begin{array}{ll}\text { CEP } & \text { Controls for Environmental Pollution } \\ \text { CERCLA } & \begin{array}{l}\text { Comprehensive Environmental Response, Compensation, } \\ \text { and Liability Act }\end{array} \\ \text { CGI } & \text { combustible gas indicator } \\ \text { cpm } & \text { counts per minute } \\ \text { dpm } & \text { disintegrations per minute } \\ \text { DOD } & \text { Department of Defense } \\ \text { DOE } & \text { Department of Energy } \\ \text { EPA } & \text { Environmental Protection Agency } \\ \text { HASRD } & \text { Health and Safety Research Division } \\ \text { HAZWRAP } & \text { Hazardous Waste Remedial Actions Program } \\ \text { HSO } & \text { health and safety officer } \\ \text { IRP } & \text { Installation Restoration Program } \\ \text { kcpm } & \text { 1000 counts per minute } \\ \text { m } & \text { meters } \\ \text { MSL } & \text { mean sea level } \\ \mu R / h & \text { micro roentgen per hour } \\ \text { NCRP } & \text { National Council on Radiation Protection } \\ \text { ORNL } & \text { Oak Ridge National Laboratory } \\ \text { PAG } & \text { Pollutant Assessments Group } \\ \text { PC } & \text { personal computer } \\ \text { PCB } & \text { polychlorinated biphenyl } \\ \text { PIC } & \text { pressurized ionization chamber } \\ \text { pCi/g } & \text { picocurie per gram } \\ \text { RDC } & \text { radon daughter concentration } \\ \text { RF } & \text { radio frequency } \\ \text { USDOI } & \text { U.S. Department of Interior } \\ \text { USGS } & \text { U.S. Geological Survey } \\ \text { USRADS } & \text { Ultrasonic Ranging and Data System } \\ & \end{array}$


ORNL/TM-12265

\section{INTERNAL DISTRIBUTION}
1. B. A. Berven
2 - 6. M. L. Espegren
7. D. K. Halford
8. M. K. Jensen
9 - 14. C. A. Little
15. P. T. Owen
16. G. A. Pierce
17. P. S. Rohwer

\author{
18. G. H. Stevens \\ 19. ORNL Technical Library, Y-12 \\ 20. Central Research Library \\ 21 - 22. Laboratory Records \\ 23. Laboratory Records - RC \\ 24. ORNL Patent Section
}

\section{EXTERNAL DISTRIBUTION}

25. S. M. Smith, Oak Ridge Institute of Science and Education, P. O. Box 2567, Grand Junction, Colorado 81502

26. G. K. Stowe, Oak Ridge Institute of Science and Education, P. O. Box 2567, Grand Junction, Colorado 81502

27. Office of Assistant Manager, Energy Research and Development, Oak Ridge Operations Office, P. O. Box 2001, Oak Ridge, Tennessee 37831-8600

28 - 37. Office of Scientific and Technical Information, U.S. Department of Energy, P. O. Box 62, Oak Ridge, Tennessee 37831 


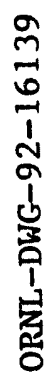

$\underset{\frac{1}{a}}{\mathbb{2}}$

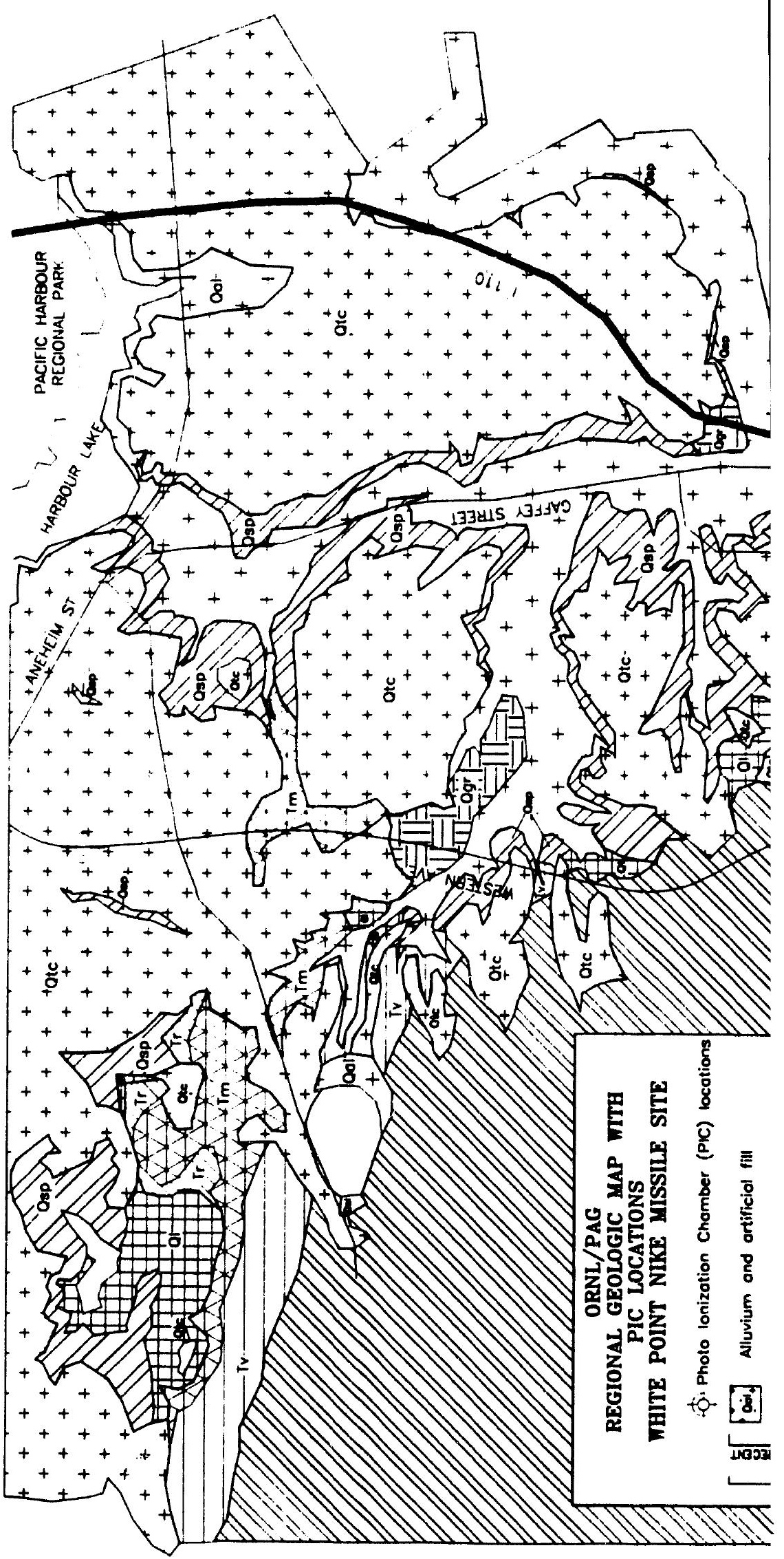




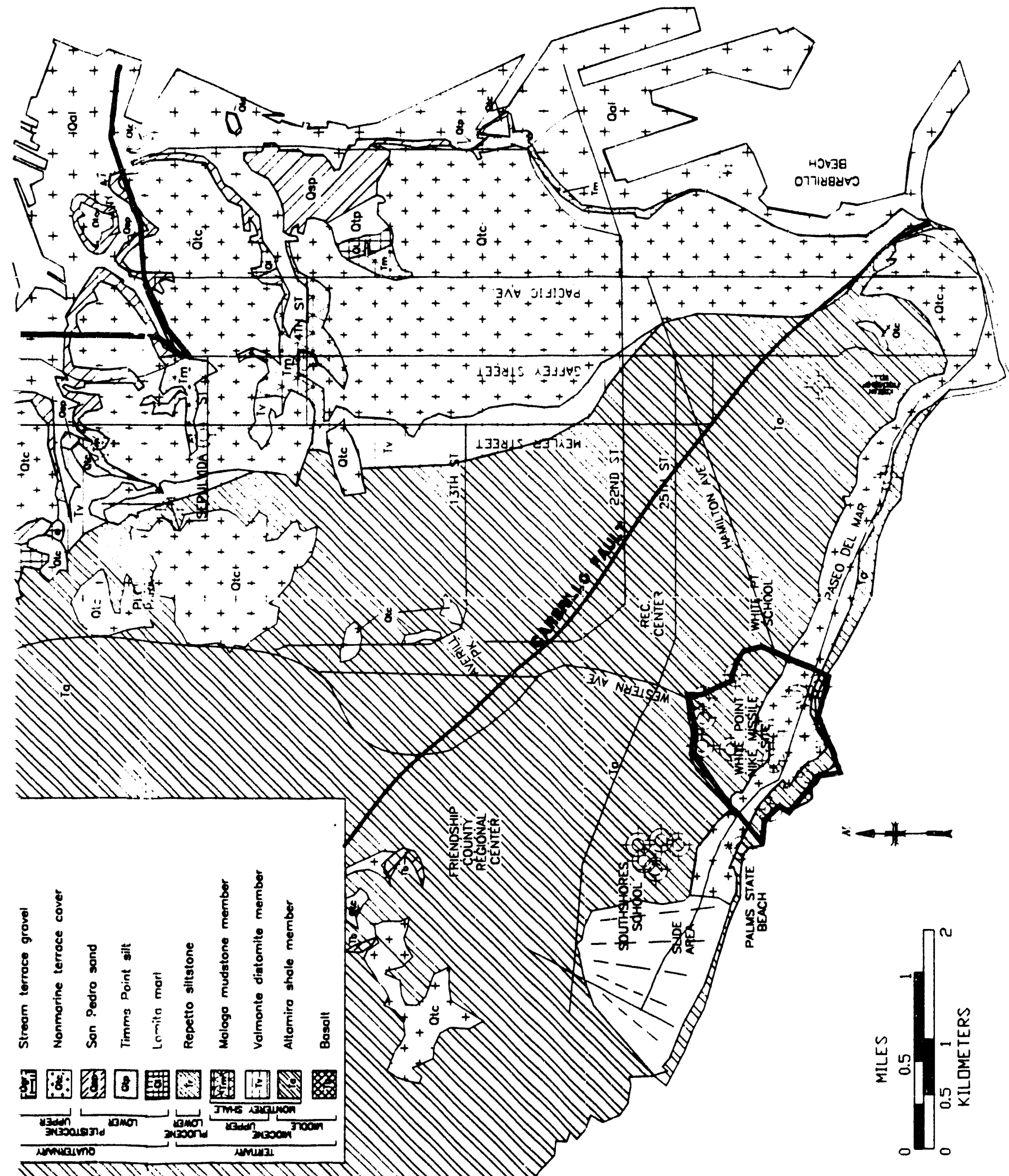




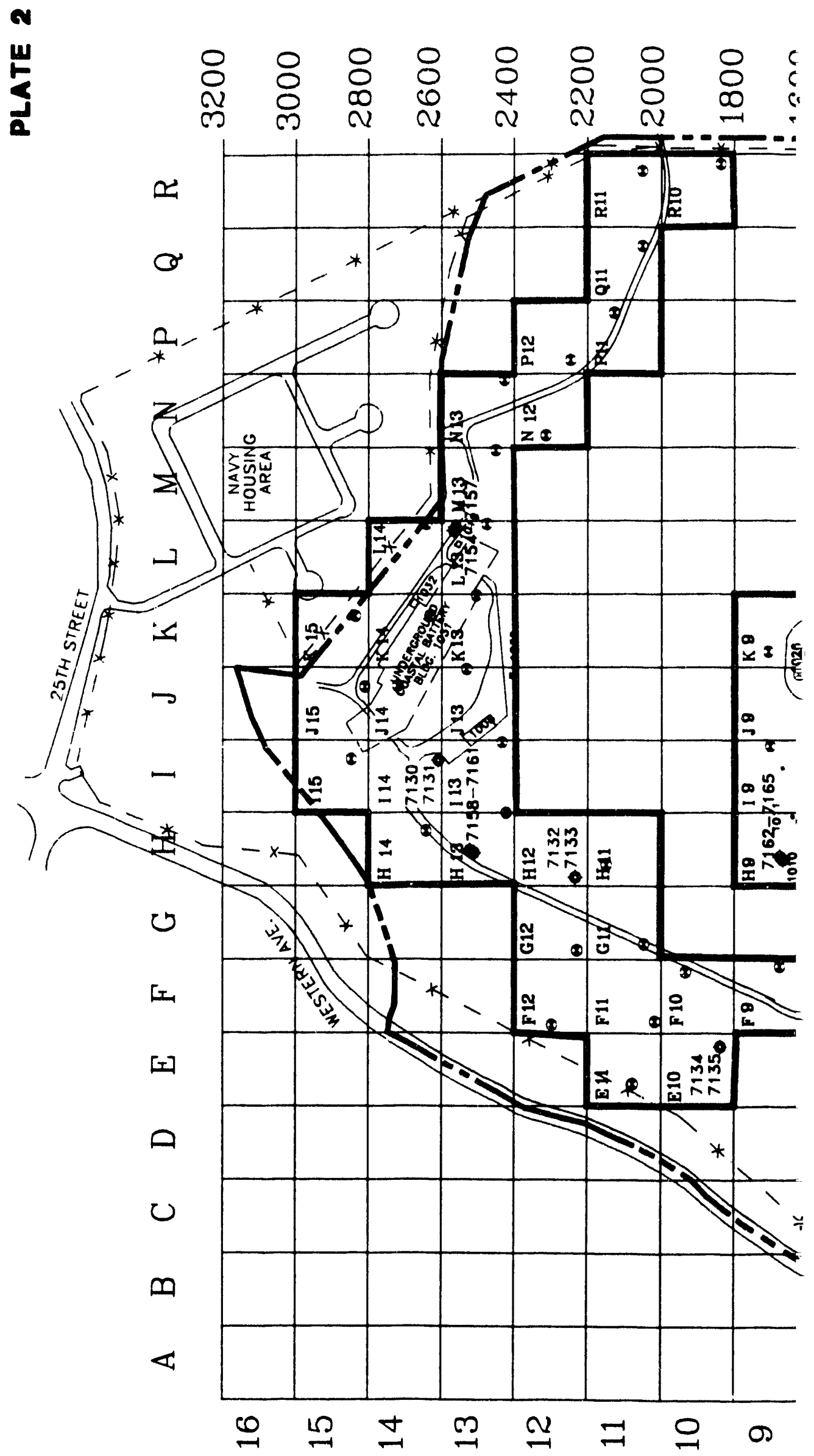




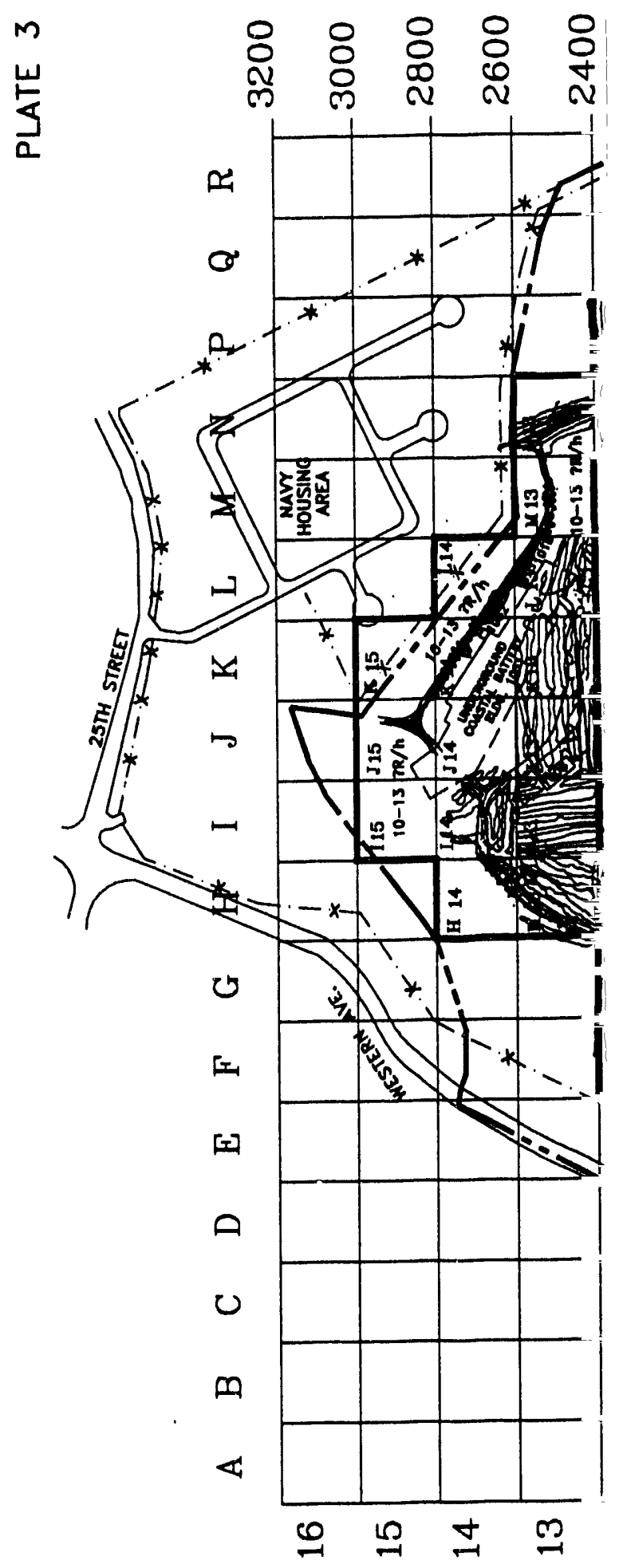




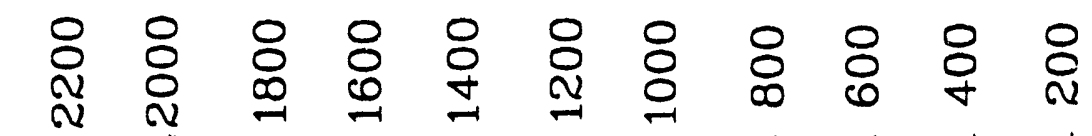
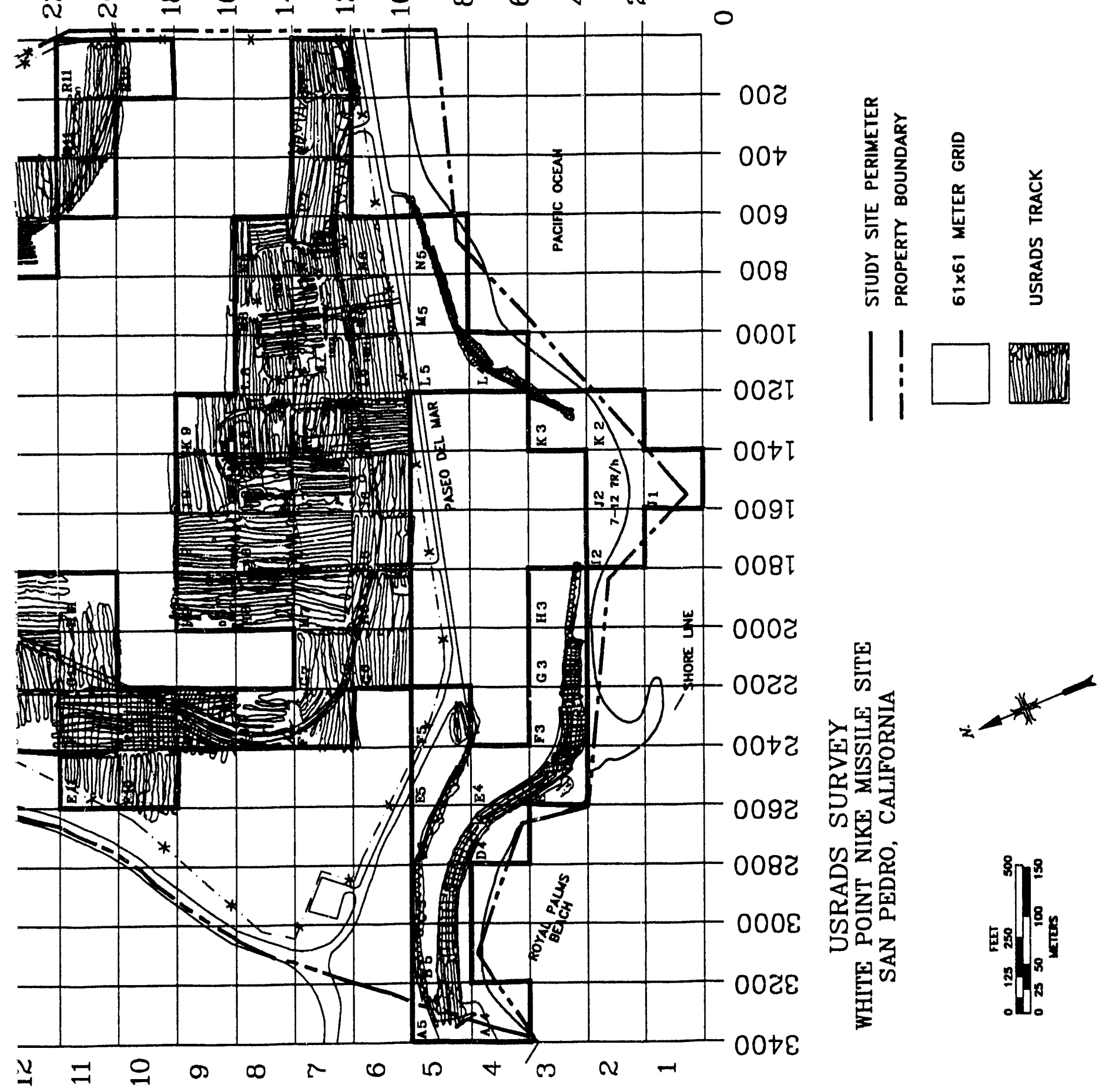

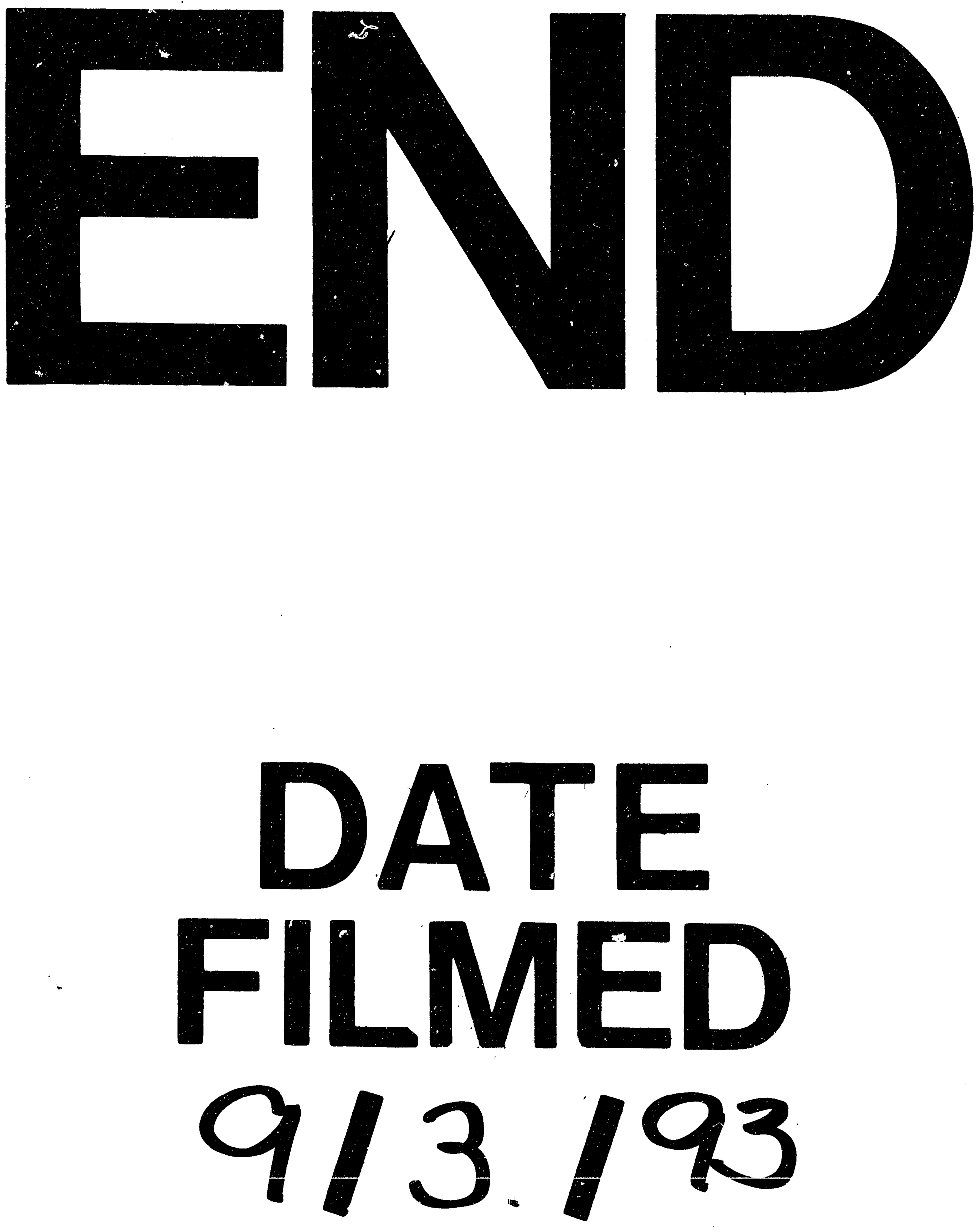


\section{.}

